\title{
Holocene vegetation and fire history of the mountains of Northern Sicily (Italy)
}

\author{
Willy Tinner $^{1} \cdot$ Elisa Vescovi $^{1} \cdot$ Jacqueline F. N. van Leeuwen $^{1} \cdot$ Daniele Colombaroli $^{1}$ \\ Paul D. Henne ${ }^{1,2} \cdot$ Petra Kaltenrieder $^{1} \cdot$ César Morales-Molino $^{1} \cdot$ Giorgia Beffa $^{1}$. \\ Bettina Gnaegi ${ }^{1}$ W. O. van der Knaap ${ }^{1}$. Tommaso La Mantia ${ }^{3} \cdot$ Salvatore Pasta $^{4}$
}

\begin{abstract}
Knowledge about vegetation and fire history of the mountains of Northern Sicily is scanty. We analysed five sites to fill this gap and used terrestrial plant macrofossils to establish robust radiocarbon chronologies. Palynological records from Gorgo Tondo, Gorgo Lungo, Marcato Cixé, Urgo Pietra Giordano and Gorgo Pollicino show that under natural or near natural conditions, deciduous forests (Quercus pubescens, Q. cerris, Fraxinus ornus, Ulmus), that included a substantial portion of evergreen broadleaved species $(Q$. suber, $Q$. ilex, Hedera helix), prevailed in the upper meso-mediterranean belt. Mesophilous deciduous and evergreen broadleaved trees (Fagus sylvatica, Ilex aquifolium) dominated in the natural or quasi-natural forests of the oro-mediterranean belt. Forests were repeatedly opened for agricultural purposes. Fire activity was closely associated with farming, providing evidence that burning was a primary land use tool since Neolithic times. Land use and fire activity intensified during the Early Neolithic at 5000 BC, at the onset of the
\end{abstract}

Willy Tinner

willy.tinner@ips.unibe.ch

1 Institute of Plant Sciences and Oeschger Centre for Climate Change Research, University of Bern, Altenbergrain 21, 3012 Bern, Switzerland

2 Geosciences and Environmental Change Science Center, U.S. Geological Survey, Denver Federal Center, Denver, CO 80225, USA

3 Department of Agrarian and Forestry Sciences (SAF), University of Palermo, Viale delle Scienze 4, 90128 Palermo, Italy

4 Department of Biology, University of Fribourg, Chemin du Musée 10, 1700 Fribourg, Switzerland
Bronze Age at $2500 \mathrm{BC}$ and at the onset of the Iron Age at 800 BC. Our data and previous studies suggest that the large majority of open land communities in Sicily, from the coastal lowlands to the mountain areas below the thornycushion Astragalus belt (ca. 1,800 m a.s.1.), would rapidly develop into forests if land use ceased. Mesophilous $\mathrm{Fa}$ gus-Ilex forests developed under warm mid Holocene conditions and were resilient to the combined impacts of humans and climate. The past ecology suggests a resilience of these summer-drought adapted communities to climate warming of about $2{ }^{\circ} \mathrm{C}$. Hence, they may be particularly suited to provide heat and drought-adapted Fagus sylvatica ecotypes for maintaining drought-sensitive Central European beech forests under global warming conditions.

Keywords Pollen - Macrofossils - Charcoal . Mediterranean - Climate change - Fagus sylvatica . Abies nebrodensis

\section{Introduction}

The mountains of Northern Sicily provide an exceptional diversity of environments (Bazan et al. 2015) over a westeast oriented range of ca. $250 \mathrm{~km}$, comprising the Sicani, Madonie, Nebrodi and Peloritani massifs. Average annual temperatures span from 18 to $20{ }^{\circ} \mathrm{C}$ in a subtropical-thermomediterranean zone at the foot of the mountains, to $10-13{ }^{\circ} \mathrm{C}$ in a boreal-altimediterranean zone at the summits, while arctic-alpine conditions prevail on the top of the Etna volcano (Viola et al. 2014). Similarly, precipitation is very variable (Fig. 1). Resulting from the temperature and precipitation gradients, humid to sub-humid environments predominate, while only a very small portion at the southeastern lowland margin of the island 


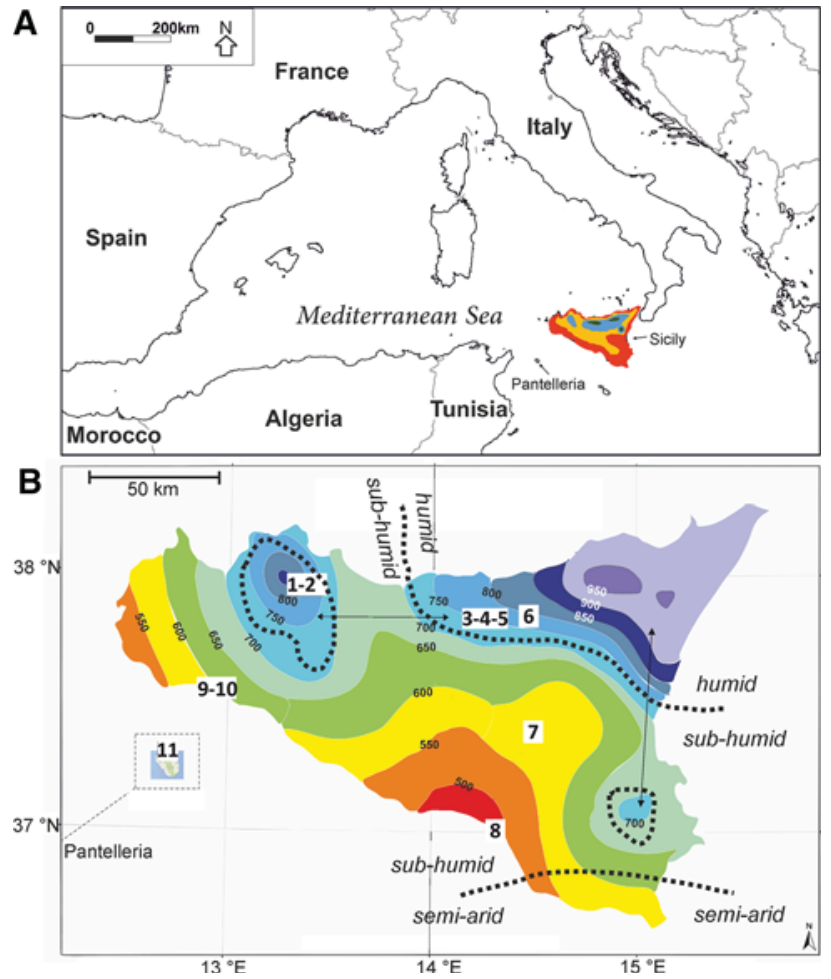

Fig. 1 a Map showing the geographical position of Sicily and Pantelleria in the Western Mediterranean. Vegetation belts of Sicily in colour: red thermo-mediterranean, orange meso-mediterranean, blue supra-mediterranean, green oro-mediterranean and alti-mediterranean; following Lang (1994). b Locations of our study sites 1 Gorgo Tondo (783 $\mathrm{m}$ a.s.1.), 2 Gorgo Lungo (877 $\mathrm{m}$ a.s.1.), 3 Urgo Pietra Giordano (1,323 $\mathrm{m}$ a.s.l.), 4 Gorgo Pollicino (1,289 $\mathrm{m}$ a.s.l.), and 5 Marcato Cixé $(1,200 \mathrm{~m}$ a.s.1.) are shown together with that of previous palaeoecological study sites in Sicily, 6 Urio Quattrocchi (1,044 $\mathrm{m}$ a.s.1.), 7 Pergusa (670 $\mathrm{m}$ a.s.1.), 8 Biviere di Gela (7 m a.s.1.), 9 Lago Preola (6 $\mathrm{m}$ a.s.1.), 10 Gorgo Basso (6 $\mathrm{m}$ a.s.1.), 11 Lago di Venere (2 $\mathrm{m}$ a.s.1.) on Pantelleria island. Sites 1-2 are located in the Sicani Mountains, the sites 3-5 at the eastern edge of the Madonie Mountains, 6 at the western edge of the Nebrodi Mountains, 7 in the hills, and 8-11 on the Mediterranean Sea coast. Mean annual precipitation isohyets are from ODA (2015), observation period 1921-2003. Humidity belts of Sicily (dotted lines, humid to semiarid) follow Baldi et al. (2004) and reveal moisture availability as an index of rainfall/potential evapotranspiration $(\mathrm{mm} / \mathrm{mm})$. Arrows link areas with same humidity classification

experiences semiarid conditions (Baldi et al. 2004; Fig. 1). Conditions in the sub-humid part of the island (Fig. 1) are comparable to those in southwestern and northeastern Iberia and considerably drier than those in mainland Italy, Sardinia or most of Greece (Baldi et al. 2004). In general, the wettest environments are located at high altitudes, and sub-humid environments at low altitudes, but the spatial complexity of precipitation and moisture availability is also related to a west-east precipitation gradient, and microclimatic effects. Other environmental factors such as soils, slope, aspect, disturbance and land use contribute to the Sicilian habitat richness, which results in high biodiversity, including endemic tree species such as Abies nebrodensis, Betula aetnensis and Zelkova sicula, and endemic herb genera such as Petagnaea and Siculosciadium (Brullo et al. 2013a, b). The undoubtedly local survival of Mediterranean species such as Zelkova sicula and Abies nebrodensis during the ice ages shows that Sicily maintained warm-temperate conditions during the harshest periods of the Quaternary, acting as an important refuge for warmthloving European species (Brullo et al. 2012).

Recent investigations have provided new insights into the vegetation and fire history of the coastal thermomediterranean vegetation belt of Sicily (Biviere di Gela, Noti et al. 2009; Gorgo Basso, Tinner et al. 2009; Lago Preola, Calò et al. 2012; Lago di Venere, Calò et al. 2013; Fig. 1), while the meso-mediterranean (Pergusa, Sadori and Narcisi 2001), supramediterranean (Urio Quattrocchi, Bisculm et al. 2012), and oro-mediterranean (Urgo Pietra Giordano, Gorgo Pollicino, Bertolani Marchetti et al. 1984) vegetation belts remain understudied. No palaeoecological studies are currently available for the uppermost vegetation type, the Astragalus thorny-cushion belt.

The primary aim of this study is to fill existing palaeoecological gaps by providing new records from the meso-mediterranean and oro-mediterranean vegetation belts. We are primarily interested in reconstructing vegetation and fire variability across the different vegetation belts of the mountains of Northern Sicily. For instance, we assess the former extent of Fagus sylvatica forests, because knowledge of the long-term dynamics of this wide-ranging European species at the extreme southern (warm-dry) edge of its range is critical for understanding the resilience of European beech forests in a warmer and drier future (Tinner and Ammann 2005). Moisture availability may have controlled the spatio-temporal dynamics of mesophilous vegetation types (Fagus, Abies communities). A late-Holocene trend to drier conditions as hypothesized for Sicily, Italy and other Mediterranean areas (e.g. Sadori et al. 2011; Mercuri et al. 2012) or aridity crises (e.g. Reed et al. 2001; Carrión 2002) should have particularly affected moisture-demanding communities such as beech forests (Bisculm et al. 2012). Alternatively or in addition to climate, vegetation composition may have been shaped by land use and anthropogenic fire disturbance, which may have reduced forest cover and promoted open land and xerophytic vegetation during the late Holocene (Colombaroli et al. 2007; Noti et al. 2009; Tinner et al. 2009; Carrión et al. 2010; Morales-Molino and García-Antón 2014). Sicily is an ideal setting to test such competing hypotheses about the roles of climate change and human impacts in a range of vegetation belts that are representative of the entire Mediterranean region, yet located within a small enough area to maintain consistency among the drivers of regional climate. 
We use new pollen, spores and microscopic charcoal series from lake and mire sediments (Fig. 1) to reconstruct the Holocene vegetation dynamics and regional fire history in the mountains of Northern Sicily. These results are compared with the already published data from Urio Quattrocchi, a site located in the same mountain range (Fig. 1; Bisculm et al. 2012). Other palaeoenvironmental and palaeoclimatic reconstructions from Sicily and Italy that have sufficient temporal resolution and chronological precision are used together with archaeological and historical evidence in order to understand the effects of climate, humans and fire on vegetational dynamics during the mid and late Holocene. After considering climatic and anthropogenic triggers of long-term vegetational change, we briefly address the implications of our study for nature conservation and forestry under global warming conditions.

\section{Study sites}

The five study sites Gorgo Tondo (783 $\mathrm{m}$ a.s.1.), Gorgo Lungo (877 m a.s.1.), Marcato Cixé (1,200 m a.s.1.), Urgo Pietra Giordano (1,323 $\mathrm{m}$ a.s.l.) and Gorgo Pollicino $(1,289 \mathrm{~m}$ a.s.l.) are located in the Northern Sicilian Mountains (Fig. 1; Table 1). Only $350 \mathrm{~m}$ separate Gorgo Tondo and Gorgo Lungo, and Marcato Cixé lies only $400 \mathrm{~m}$ from Urgo Pietra Giordano. The latter two sites are at ca. $4 \mathrm{~km}$ from Gorgo Pollicino and $63 \mathrm{~km}$ from Gorgo Tondo and Gorgo Lungo. The mountains of Northern Sicily are mainly composed of sandstone, marl, flysch and carbonatic rocks (Lentini and Carbone 2014). The origin of the lake and wetland basins is unclear, but was probably connected to karstic or possibly other geomorphological processes such as landslides and debris flows. The small pond Gorgo Lungo (Table 1) has stable water depths with a conspicuous freshwater turtle population (Emys trinacris). At Gorgo Pollicino, water levels must have recently increased as evidenced by a submerged fence that may have divided the pond into two properties. Gorgo Tondo has recently almost completely lost its water body, while Marcato Cixé and Urgo Pietra Giordano are strongly human-influenced small mires (Table 1). We use the climatic data from Ficuzza (681 m a.s.1.), Petralia Sottana (932 $\mathrm{m}$ a.s.1.), Gangi (930 $\mathrm{m}$ a.s.1.) and Geraci Siculo (1,070 $\mathrm{m}$ a.s.1.) to infer the climatic conditions at our sites (ODA 2015). Mean annual temperatures (1960-1989) span from 14 to $15{ }^{\circ} \mathrm{C}$ at the meso-mediterranean sites (Gorgo Tondo, Gorgo Lungo) to $11-12{ }^{\circ} \mathrm{C}$ at the oro-mediterranean sites (Marcato Cixé, Urgo Pietra Giordano, Gorgo Pollicino). Mean July temperatures are $23-24{ }^{\circ} \mathrm{C}$ at the meso-mediterranean and $21-22{ }^{\circ} \mathrm{C}$ at the oro-mediterranean sites. The altitudinal temperature gradient is more pronounced during the winter rain season, with mild January means of $7-8{ }^{\circ} \mathrm{C}$ at the meso-mediterranean, and $2-3{ }^{\circ} \mathrm{C}$ at the oro-mediterranean sites. Mean annual precipitation is $750-800 \mathrm{~mm}$ (meso-mediterranean) to 800-950 mm (oro-mediterranean sites). Summer precipitation (sum of June, July and August) is strongly reduced, reaching only $35 \mathrm{~mm}$ at the meso-mediterranean and $45 \mathrm{~mm}$ at the oro-mediterranean sites (ODA 2015).

In this study, vegetation type denominations (i.e. thermo-mediterranean, meso-mediterranean, supramediterranean, oro-mediterranean, alti-mediterranean) are used in a community sense following e.g. Reisigl et al. (1992) and Lang (1994) and are not defined by climatic or bioclimatic parameters. In the thermo-mediterranean belt at ca. 0-500 $\mathrm{m}$ a.s.1., evergreen broadleaved trees, shrubs and palms prevail (e.g. Quercus ilex, Q. coccifera, Q. suber, Olea europaea, Pistacia lentiscus, Ceratonia siliqua, Chamaerops humilis). Mixed deciduous-evergreen broadleaved oak forests (e.g. Q. ilex, $Q$. suber, $Q$. pubescens, $Q$. cerris) form the meso-mediterranean belt at ca. 500-900 m a.s.l., while deciduous mediterranean oaks (e.g. $Q$. pubescens, $Q$. cerris, $Q$. petraea) dominate in the supramediterranean belt at ca. 900-1,200 m a.s.l. together with sporadic conifers. Above these three Mediterranean vegetation belts, two further belts occur, which are related to Central European and Central Asian mountain vegetation. The oro-mediterranean belt at ca. 1,200-1,900 m a.s.1. in which Fagus sylvatica is dominant, accompanied by Ilex aquifolium, Quercus petraea and conifers such as Pinus nigra subsp. laricio, Taxus baccata or Abies nebrodensis is closely related to the central European mountain vegetation

Table 1 Site characteristics

\begin{tabular}{llllllll}
\hline Site name & Site type & Surface (ha) & Aspect of slope & Latitude & Longitude & Elevation (m a.s.l.) & Vegetation type \\
\hline Gorgo Tondo & Pond & 0.6 & South-east & $37^{\circ} 54^{\prime} 04^{\prime \prime} \mathrm{N}$ & $13^{\circ} 24^{\prime} 36^{\prime \prime} \mathrm{E}$ & 783 & Meso-mediterranean \\
Gorgo Lungo & Pond & 0.2 & South-east & $37^{\circ} 54^{\prime} 04^{\prime \prime} \mathrm{N}$ & $13^{\circ} 24^{\prime} 30^{\prime \prime} \mathrm{E}$ & 877 & Meso-mediterranean \\
Marcato Cixé & Mire & 0.4 & North & $37^{\circ} 51^{\prime} 01^{\prime \prime} \mathrm{N}$ & $14^{\circ} 07^{\prime} 55^{\prime \prime} \mathrm{E}$ & 1,200 & Oro-mediterranean \\
Gorgo Pollicino & Pond & 0.2 & South & $37^{\circ} 49^{\prime} 25^{\prime \prime} \mathrm{N}$ & $14^{\circ} 07^{\prime} 38^{\prime \prime} \mathrm{E}$ & 1,289 & Oro-mediterranean \\
Urgo Pietra Giordano & Mire & 0.2 & North & $37^{\circ} 51^{\prime} 10^{\prime \prime} \mathrm{N}$ & $14^{\circ} 07^{\prime} 40^{\prime \prime} \mathrm{E}$ & 1,323 & Oro-mediterranean \\
\hline
\end{tabular}




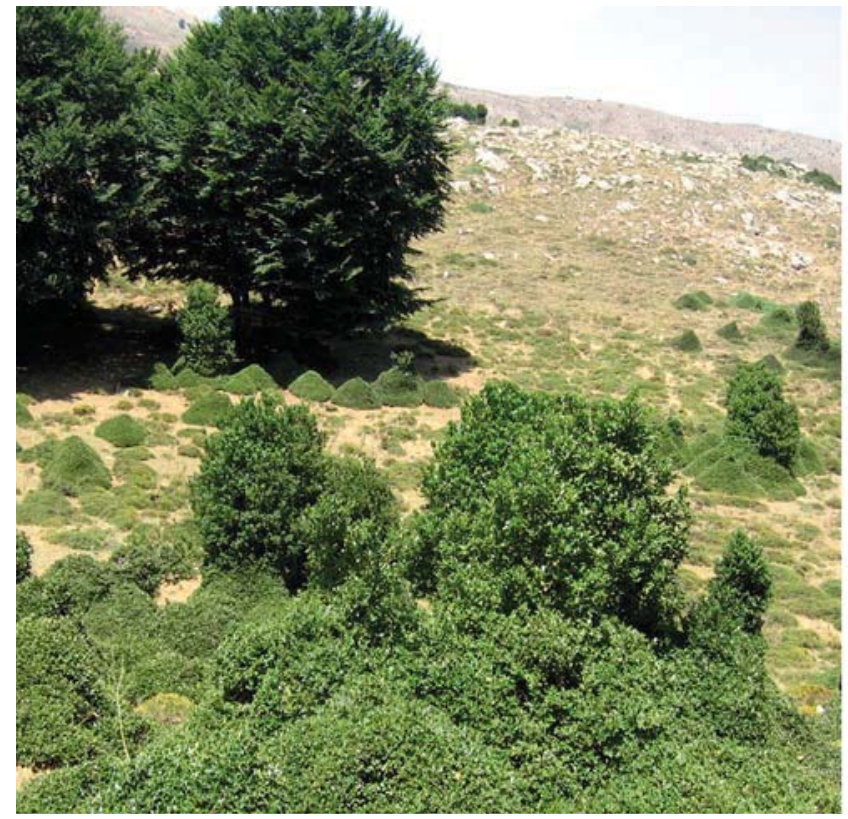

Fig. 2 Holly-beech stands at Marcato Cixé. In the left hand image conical forms of Ilex aquifolium (holly) as a result of goat and sheep browsing. Once individuals of I. aquifolium have reached a certain height $(\mathrm{ca} .1 \mathrm{~m})$ they can escape browsing, developing a rounded form. Two Fagus sylvatica (beech) trees are growing in the background on the left. In the right hand image holly stands grow

belt (Reisigl et al. 1992; Pignatti 1997; Ellenberg 2009). Above the oro-mediterranean belt an extreme outlier of Central Asian high-mountain vegetation occurs at ca. 1,900-2,800 $\mathrm{m}$ a.s.l. (Pignatti 1997), the alti-mediterranean thorny cushion belt (Reisigl et al. 1992). This special vegetation type, which also occurs in Southern Iberia, the Atlas Range in Northern Africa, and in continental and insular Greece, is characterized by Astragalus shrublands (e.g. A. siculus, A. nebrodensis; Frei 1940; Allen 2001; Brullo et al. 2005) and was possibly established during the Messinian salinity crisis, when drought-adapted thorny Central Asian plant species invaded the desiccated Mediterranean basin (Pignatti 1997; Guarino et al. 2006).

Our sites are located in the upper meso-mediterranean and the lower oro-mediterranean vegetation belts, where deciduous broadleaved species prevail in the forests together with evergreen broadleaved species (lower altitudes) or conifers (higher altitudes). Gorgo Tondo and Gorgo Lungo are in the densely forested area of the Ficuzza natural preserve south of Palermo. Around these sites, pine (Pinus pinea) afforestations predominate. Hedera helix is abundant in the forests of Ficuzza underscoring the rather oceanic climate in this area (Fig. 1). Gorgo Lungo has an Ulmus canescens belt of a few metres width around the lake. Gorgo Pollicino is located in an open xeric to mesophilous grassland and shrubland environment

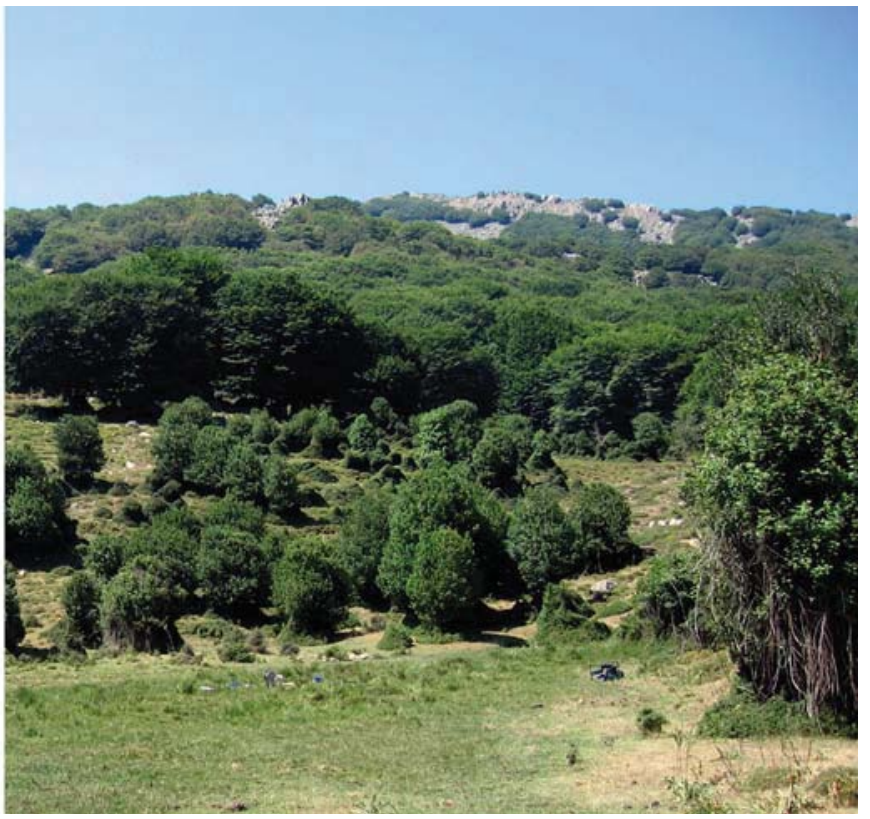

in front of a dense beech forest. The mire Marcato Cixé is the flat area in the foreground. The contrast between dry grassland (left image background) and moist forested environments (right image) is strong and mainly depends on land use intensity and degree of deforestation. Photos W. Tinner 2008

(Bertolani Marchetti et al. 1984). Marcato Cixé is located in an open mesophilous grassland (e.g. Plantago cupanii, included in the Plantago coronopus pollen type) with abundant holly (Ilex aquifolium) shrubs and trees. This site is located at the lower local beech (Fagus sylvatica) forest limit and strongly impacted by goats, sheep, cattle and horses (Fig. 2). Finally, Urgo Pietra Giordano lies within a beech forest which grows ca. $150 \mathrm{~m}$ above its current lower limit.

\section{Methods}

\section{Coring and chronology}

At all study sites, parallel cores were taken ca. $1 \mathrm{~m}$ apart from the centre of the basins, with a modified Streif-Livingstone piston corer $4.8 \mathrm{~cm}$ in diameter (Lang 1994). The cores were visually correlated according to lithostratigraphy. AMS (Accelerated Mass Spectrometry) radiocarbon ages were measured only on terrestrial plant macrofossils extracted from sediment samples (Table 2). The ${ }^{14} \mathrm{C}$ dates were converted to calibrated ages (cal BP, cal AD, cal BC) with the program Calib version 7.0 (Reimer et al. 2013). The age-depth models are based on linear interpolation 
Table 2 Radiocarbon dates

\begin{tabular}{|c|c|c|c|c|c|c|}
\hline Site & Lab code & $\begin{array}{l}\text { Depth } \\
(\mathrm{cm})\end{array}$ & Material & $\begin{array}{l}{ }_{(\mathrm{BP})}^{14} \mathrm{C} \text { dates } \\
\end{array}$ & $\begin{array}{l}\text { Age in } \\
\text { diagram } \\
(\text { cal BP })^{a, b}\end{array}$ & $\begin{array}{l}2 \sigma \text { confidence } \\
\text { intervals } \\
\text { (cal BP) }\end{array}$ \\
\hline \multirow[t]{4}{*}{ Gorgo Tondo } & $\begin{array}{l}\text { Poz- } \\
\quad 62143\end{array}$ & 100-102 & deciduous Quercus L, Rubus S, W, CH & $710 \pm 30$ & 669 & $566-693$ \\
\hline & $\begin{array}{l}\text { Poz- } \\
62144\end{array}$ & $180-182$ & $\begin{array}{l}\text { deciduous TW P, BS, } \\
\text { Corrigiola litoralis } \mathrm{S}\end{array}$ & $1,260 \pm 30$ & 1,218 & $1,087-1,281$ \\
\hline & $\begin{array}{l}\text { Poz- } \\
19124\end{array}$ & $265-267$ & charred $\mathrm{B}, \mathrm{P}$ & $2,900 \pm 35$ & 3,035 & $2,930-3,161$ \\
\hline & $\begin{array}{l}\text { Poz- } \\
\quad 62146\end{array}$ & $336-340$ & $\mathrm{CH}$ & $3,955 \pm 35$ & 4,422 & $4,292-4,520$ \\
\hline \multirow[t]{3}{*}{ Gorgo Lungo } & $\begin{array}{l}\text { Poz- } \\
19121\end{array}$ & 431 & $\mathrm{~B}, \mathrm{P}$ & $1,330 \pm 30$ & 1,273 & $1,184-1,301$ \\
\hline & $\begin{array}{l}\text { Poz- } \\
19122\end{array}$ & $604-605$ & $\begin{array}{l}\text { deciduous Quercus L, Quercus BS, P, } \\
\text { TW }\end{array}$ & $1,750 \pm 30$ & 1,658 & $1,566-1,726$ \\
\hline & $\begin{array}{l}\text { Poz- } \\
19123\end{array}$ & $726-733$ & $\mathrm{CH}$ & $3,445 \pm 30$ & 3,703 & $3,633-3,828$ \\
\hline Gorgo Pollicino & $\begin{array}{l}\text { Poz- } \\
19090\end{array}$ & $232-234$ & $\mathrm{TW}, \mathrm{CH}$ & $2,325 \pm 30$ & 2,344 & $2,207-2,425$ \\
\hline Marcato Cixé & $\begin{array}{l}\text { Poz- } \\
29365\end{array}$ & $176-178$ & W & $935 \pm 30$ & 853 & $789-923$ \\
\hline \multirow[t]{10}{*}{$\begin{array}{l}\text { Urgo Pietra } \\
\text { Giordano }\end{array}$} & $\begin{array}{l}\text { Poz- } \\
\quad 62142\end{array}$ & $26-28$ & $\mathrm{CH}$ & $1,810 \pm 30$ & 1,750 & $1,628-1,822$ \\
\hline & $\begin{array}{l}\text { Poz- } \\
60130\end{array}$ & $47-51$ & $\begin{array}{l}\text { deciduous } \mathrm{P}, \mathrm{CH}, \mathrm{BS}, \\
\text { Rubus } \mathrm{S} \text {, Carex } \mathrm{S}\end{array}$ & $3,225 \pm 30$ & 3,440 & $3,378-3,555$ \\
\hline & $\begin{array}{l}\text { Poz- } \\
\quad 60129\end{array}$ & $83-85$ & deciduous $\mathrm{P}, \mathrm{CH}$ & $4,175 \pm 30$ & Rejected & Rejected \\
\hline & $\begin{array}{l}\text { Poz- } \\
36120\end{array}$ & $97-99$ & Fagus TW & $4,015 \pm 35$ & 4,482 & $4,417-4,569$ \\
\hline & $\begin{array}{l}\text { Poz- } \\
\quad 60128\end{array}$ & $127-129$ & deciduous TW, dicot. $\mathrm{L}$ & $4,075 \pm 30$ & 4,565 & $4,442-4,804$ \\
\hline & $\begin{array}{l}\text { Poz- } \\
\quad 36119\end{array}$ & $177-179$ & Fagus BS, TW & $4,485 \pm 35$ & 5,167 & $4,980-5,295$ \\
\hline & $\begin{array}{l}\text { Poz- } \\
28018\end{array}$ & $228-229$ & TW & $5,050 \pm 35$ & 5,818 & $5,668-5,906$ \\
\hline & $\begin{array}{l}\text { Poz- } \\
36121\end{array}$ & $285-287$ & $\mathrm{~S}, \mathrm{~W}, \mathrm{CH}$ & $5,550 \pm 40$ & 6,347 & $6,288-6,406$ \\
\hline & $\begin{array}{l}\text { Poz- } \\
\quad 60127\end{array}$ & $311-313$ & Rubus S, Carex S & $5,815 \pm 35$ & 6,622 & $6,503-6,718$ \\
\hline & $\begin{array}{l}\text { Poz- } \\
\quad 60126\end{array}$ & $333-337$ & $\mathrm{~W}$, deciduous $\mathrm{P}, \mathrm{BS}$ & $6,060 \pm 100$ & 6,927 & $6,672-7,171$ \\
\hline
\end{tabular}

$B$ bark, $P$ periderm, $L$ leaf, $B S$ bud scale, $C H$ charcoal, $T W$ twig, $S$ seed, $W$ wood

a Median of the probability distribution

${ }^{\mathrm{b}}$ Calibrated dates obtained using CALIB 7.0 (Reimer et al. 2013)

between and beyond calibrated ages. We preferred this simple approach to more complex ones (e.g. general additive models GAM, Heegaard et al. 2005) because it is particularly suited for chronologies with reduced numbers of dates per site (Berglund and Ralska-Jasiewiczowa 1986; Table 2) and because it gives full weight to the dates obtained on plant terrestrial macrofossils. The only site with more dates, Urgo Pietra Giordano, also yielded satisfactory results with linear interpolation.

\section{Pollen, spores, microscopic charcoal and macrofossil} analyses

Chemical and physical pollen slide preparation followed standard procedures for glycerine samples (Moore et al. 1991). Lycopodium spore tablets were added to palynological samples of $1 \mathrm{~cm}^{3}$ sediment for estimating pollen and spore concentrations (grains $\mathrm{cm}^{-3}$ ) and influx (grains $\mathrm{cm}^{-2}$ year $^{-1}$; Stockmarr 1971). Palynological 

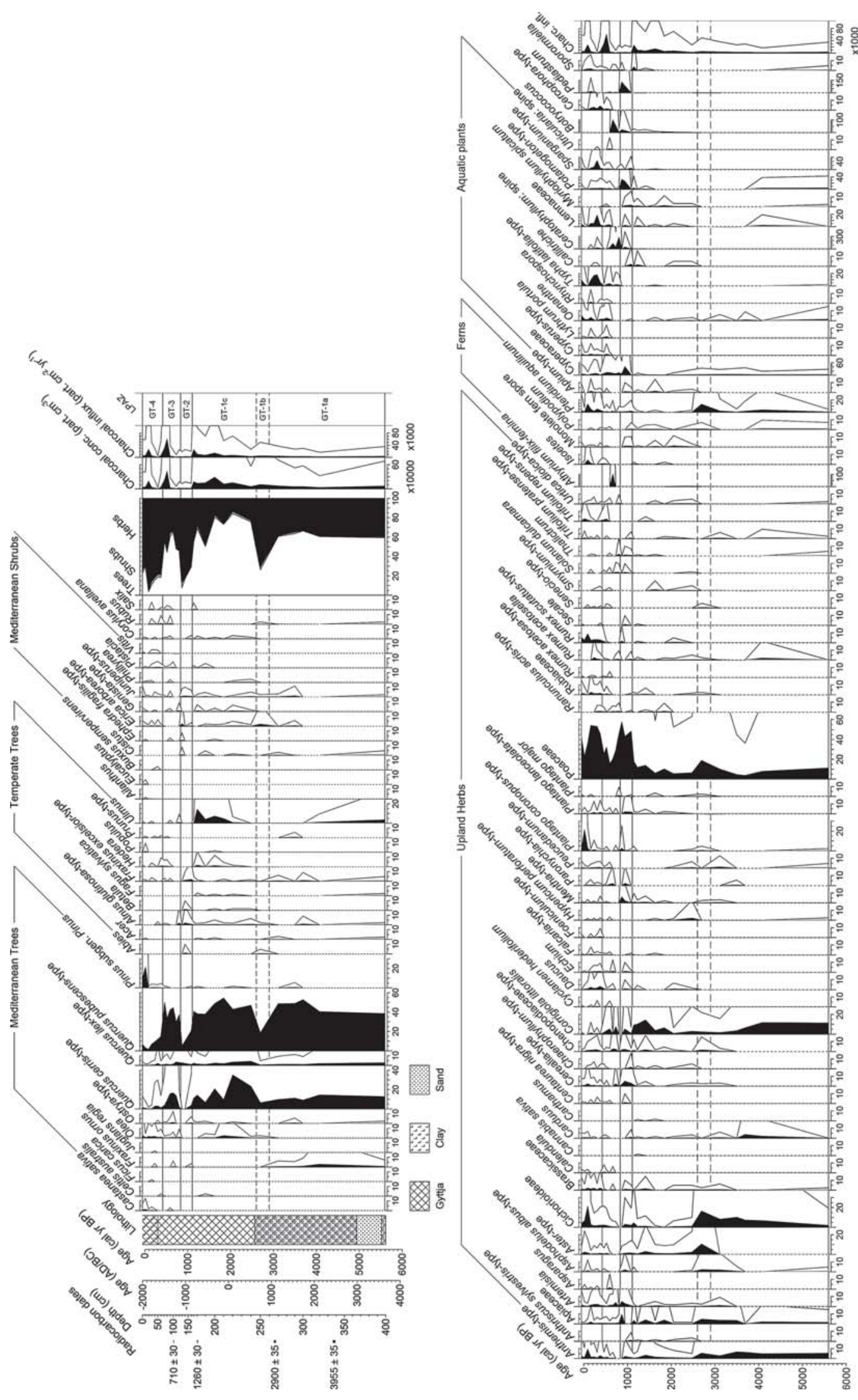

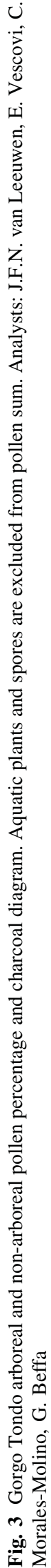


identification was made with palynological keys (Punt et al. 1976-1996, 1994; Moore et al. 1991; Beug 2004), atlases (e.g. Reille 1992) and the reference collection of the Institute of Plant Sciences of the University of Bern. Counts per palynological sample reached sums of ca. 400-600, excluding aquatic pollen and spores. The pollen diagrams were subdivided into local pollen assemblage zones (LPAZ) using the zonation method of optimal partitioning (Birks and Gordon 1985) as implemented in the program ZONE 1.2 (Juggins 1991). To determine the number of statistically significant zones in diagrams, we used the program BSTICK (Bennett 1996). Zones were subdivided in subzones to allow more detailed description of vegetation history; however, the subzones are not statistically significant. Microscopic charcoal particles longer than $10 \mu \mathrm{m}$ (or area $>75 \mu^{2}$ ) were counted in pollen slides following Tinner and $\mathrm{Hu}$ (2003) and Finsinger and Tinner (2005) to estimate charcoal number concentration (particles $\mathrm{cm}^{-3}$ ) and influx (particles $\mathrm{cm}^{-2}$ year ${ }^{-1}$ ) as a proxy for regional fire activity (mainly fire frequency, Tinner et al. 1998; Conedera et al. 2009). For our interpretation we assign Quercus cerris type to Q. cerris for the sites above 1,000 m a.s.l. (Gorgo Pollicino, Marcato Cixé, Urgo Pietra Giordano), given that at present $Q$. suber is very rare or even completely absent above the mesomediterranean belt. $Q$. suber and $Q$. cerris co-occur at Gorgo Lungo and Gorgo Tondo, thus we prefer to avoid attributing this pollen type to one of the two species at the meso-mediterranean sites. We sub-sampled $10-12 \mathrm{~cm}^{3}$ of sediment for macrofossil analysis at Urgo Pietra Giordano. Sample thickness was $2 \mathrm{~cm}$. The plant macrofossils were sieved with water and a mesh width of $0.2 \mathrm{~mm}$. For macrofossil identification we used reference material from the Institute of Plant Sciences and the Botanical Garden at the University of Bern.

\section{Results and interpretations}

\section{Coring, chronology and lithology}

Water depths at the coring spots in the centre of the ponds were $11 \mathrm{~cm}$ at Gorgo Tondo, $168 \mathrm{~cm}$ at Gorgo Lungo and $202 \mathrm{~cm}$ at Gorgo Pollicino. The coring depths span from $737 \mathrm{~cm}$ (Gorgo Lungo) to $190 \mathrm{~cm}$ (Marcato Cixé). At all sites we stopped coring when friction was too high to continue. Eighteen ${ }^{14} \mathrm{C}$ dates were accepted (Table 2) and one was rejected. The rejected date comes from Urgo Pietra Giordano and is too old if compared with the two dates that follow down-core (temporal inversion). The diagrams (Figs. 3, 4, 5, 6, 7, 8) show the age-depth linkages and thus the sediment deposition rates (in $\mathrm{cm}$ per unit time). Gorgo Tondo shows increased sedimentation rates in the top $180 \mathrm{~cm}$ (last 1,300 years, Fig. 3), similarly sedimentation rates are higher at Gorgo Lungo in the uppermost $600 \mathrm{~cm}$ (last 1,700 years). Unchanging sedimentation rates at Marcato Cixé and Gorgo Pollicino are caused by the presence of just one date per site. Finally, Urgo Pietra Giordano shows reduced sedimentation rates at depths 0-100 cm (last 4,500 years).

Fine-grained organic material (gyttja) predominates in the top sediments of Gorgo Tondo (0-244 cm, last 2,700 years), Gorgo Lungo (0-300 cm, last 800 years), Gorgo Pollicino (0-132 cm, last 1,300 years) and Urgo Pietra Giordano (0-264 cm, last 6,200 years), while Marcato Cixé contains minerogenic detrital layers (silt, sand and occasionally pebbles) throughout the sequence (Table 3). Mixtures of fine-grained organic and minerogenic sediments characterize all sites at intermediate sediment depths with the exception of Gorgo Pollicino, which predominantly contains coarse-grained sandy sediments. The bottoms of all sites are dominated by coarse-grained sands. Fine-grained organic layers indicate stable environment and autochthonous sediment formation, while minerogenic and particularly sandy sediments suggest unstable catchment conditions with substantial erosional input.

\section{Pollen and charcoal-inferred vegetation and fire history}

\section{Gorgo Tondo}

The oldest sediments of the Gorgo Tondo record are dated around 5,600 cal BР (3650 BC, Fig. 3) and roughly fall into the mid to late Holocene transition period. Moderately high arboreal pollen percentages (AP, ca. $60 \%$ ) suggest the predominance of open deciduous-evergreen oak forests (Q. pubescens- and $Q$. cerris-type with admixed $Q$. ilex, Ulmus and Fraxinus ornus). Upland herbaceous communities were dominated by Cichorioideae, Anthemis-type and Poaceae. Pollen of crops (e.g. Cerealia-type) or weeds (e.g. Plantago lanceolata-type) is absent, suggesting that agricultural activities were marginal or even completely lacking. The high abundance of Corrigiola litoralis (ca. $10 \%$ ) points to seasonally inundated lake-shores, while water plants such as Potamogeton and Myriophyllum spicatum occurred in the lake. Microscopic charcoal influx indicates that fire activity was very low during this early period with negligible human impact.

Zonation results suggest that terrestrial vegetation composition remained relatively stable over the millennia until ca. 1,100 cal вр (local pollen assemblage zone LPAZ GT-1, 3650 BC-AD 850). This concerns the main taxa; however, at the onset of the Iron Age (Leighton 1999) human impact on vegetation became relevant (subzone 

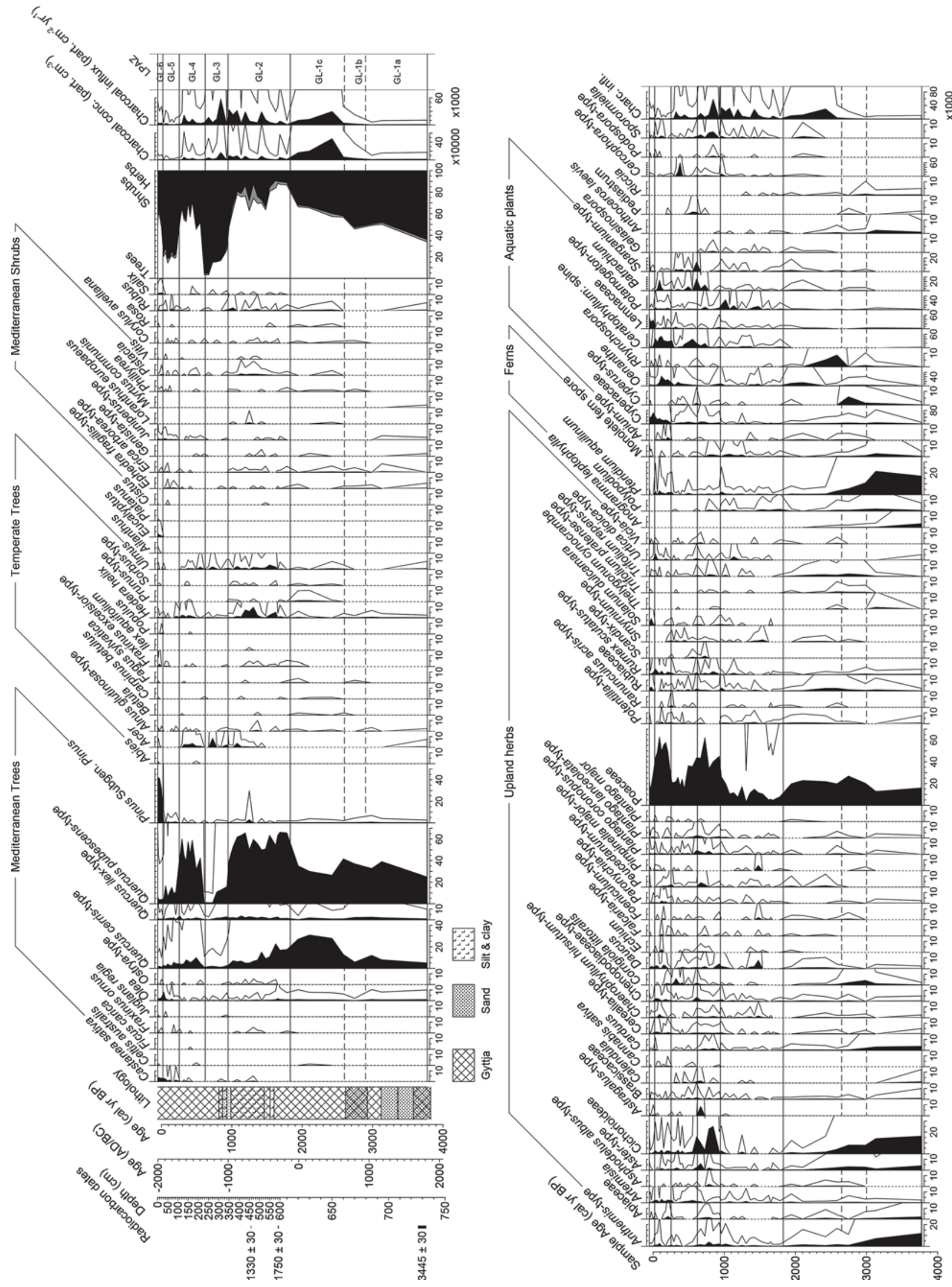
4Fig. 4 Gorgo Lungo arboreal and non-arboreal pollen percentage and charcoal diagram. Aquatic plants and spores are excluded from pollen sum. Analysts: J.F.N. van Leeuwen, E. Vescovi

GT-1b, 2,900-2,600 cal BP, 950-700 вC). During this period, pollen of crops and weeds (e.g. Cerealia-type, Plantago lanceolata-type) suggests noticeable arable and pastoral farming in the Gorgo Tondo area, and declines of arboreal pollen (AP) from 60 to $25 \%$ point to substantial forest openings. Low-impact land use had started earlier, at the Early/Middle Bronze Age transition at ca. 3,500 cal вр (1550 BC), as documented by a rise of Cerealia-type, Artemisia, Asphodelus albus-type, Brassicaceae, Chenopodiaceae, Mentha-type and Peucedanum-type. In contrast to the Iron Age with extensive forest opening, Middle and Late Bronze Age agriculture hardly affected vegetation structure in the area. Human impact remained low during Greek and Roman Times (GT-1c). Intensive agriculture became established only during the Middle Ages at 1,100-850 cal вр (AD 850-1100; GT-2) and forests were almost completely cleared (AP $<10 \%$ ). After a transient (but statistically significant) phase of forest recovery and field and pasture abandonment at 850-400 cal BP (AD 1100-1550, GT-3), open lands (AP $<10 \%$ ) were re-established during LPAZ GT-4 (AD 1550 to present). During this period with intense agricultural activities, the fruit trees Castanea sativa and Olea europaea expanded. Finally, forests became partly reestablished ca. 100 years ago, when Pinus pinea was planted in the area (Fig. 3).

Charcoal-inferred fire activity preceded and/or followed pollen-inferred agricultural activity (e.g. Cerealia-type, Cichorioideae, Daucus, Rumex acetosa-type, Trifolium repens-type), we thus assume that most fires in the area were of human origin. While fire activity was low prior to ca. 3,000 cal BP (ca. 1000 BC), it increased subsequently, to peak around 500 years ago. Aquatic plants also show strong linkages with medieval and modern cultural phases (Fig. 3b). We assume that they primarily reflect lake level and nutrient changes in response to land use. For instance, the Potamogeton-type and Pediastrum expansion (GT-2) was followed by a Typha latifolia-type increase (GT-4), suggesting important decreases of lake levels during cultural phases, possibly for irrigation purposes. Indeed, no substantial oscillations of water-plant populations can be inferred from the palynological record prior to humanization of vegetation (i.e. 5,600-1,100 cal BP, 3650 BC-AD 850).

\section{Gorgo Lungo}

The pond lies close to Gorgo Tondo and thus it is not surprising that the two sites present similar biostratigraphic patterns. AP of ca. 40-60 \% suggests open vegetation conditions 3,800-1,850 cal вр (1850 вС-AD 100) during LPAZ GL-1 (Fig. 4). Forests were mainly composed of deciduous and evergreen oaks ( $Q$. pubescens-type, $Q$. cerris-type) in which Hedera helix was important. Q. ilex, Olea europaea, and Erica arborea were present but not abundant. Open land was composed of meadows of e.g. Anthemis-type, Cichorioideae, Carduus, Trifolium repens-type, T. pratense-type and Rubiaceae, while Corrigiola litoralis was abundant on the sandy lake shores around Gorgo Lungo. Agriculture probably occurred from the beginning of the record (e.g. Cerealia-type, Plantago lanceolata-type, Rumex scutatustype), which falls in the Early Bronze Age.

During subzone GL-1a Pteridium aquilinum was very prominent (ca. $20 \%$ ), on an average about 10 times more than at Gorgo Tondo and this may indicate strong local forest disturbance such as grazing (but not fire, see below). In subzone GL-1b (3,000-2,600 cal BP), pollen of Foeniculum-type, Pimpinella major-type and Asphodelus albus-type appears, and Poaceae, Artemisia and Aster-type reach a transient peak, while Anthemis-type, Cichorioideae, Carduus, and Apiaceae decline. This compositional shift, which suggests conversion of meadows into grasslands (e.g. more intense grazing, see Cercophora-type, Podospora-type, Sporormiella increases), continued during GL-1c (2,600-1,850 cal BP), when open land communities declined despite the expansions of Daucus, Peucedanumtype, Potentilla-type, Plantago major, Falcaria-type and Smyrnium-type. Former open land was primarily colonized by Quercus cerris and/or $Q$. suber ( $Q$. cerris-type), which gradually became co-dominant in the oak forests.

High arboreal pollen abundance (AP $>80 \%)$ suggests that forest closure reached a maximum during GL-2 (1,850-1,000 cal BP, AD 100-950), when Hedera helix (>10\%) and Ulmus (ca. $5 \%$ ) peaked. Despite forest closure, arable and pastoral farming was probably still practiced (e.g. Cerealia-type, Plantago lanceolata-type, Foeniculum-type, Urtica dioica, Castanea, Gelasinospora, Sporormiella), possibly in small openings. Subsequently, forests collapsed at 1,000-600 cal BP (AD 950-1350, GL-3) and the new open land became dominated by Cichorioideae, Aster-type, Plantago coronopus-type, P. lanceolata-type and Poaceae. This vegetational shift, together with increases of Cercophora-type, Podospora-type and Sporormiella, points to intense pastoral activities, while arable farming (Cerealia-type) increased but did not become important. Oak forests recovered almost fully $(\mathrm{AP}>60 \%)$ at $600-250 \mathrm{cal}$ BP (AD 1350-1700, GL-4), before a new intense land use phase began at ca. 250-50 cal вP (AD 1700-1900, GL-5), with expansions of e.g. Castanea sativa, Olea europaea, Cerealia-type, Daucus, Cannabis sativa, Artemisia and Urtica dioica-type. Finally, wide Pinus and Eucalyptus afforestations partially 

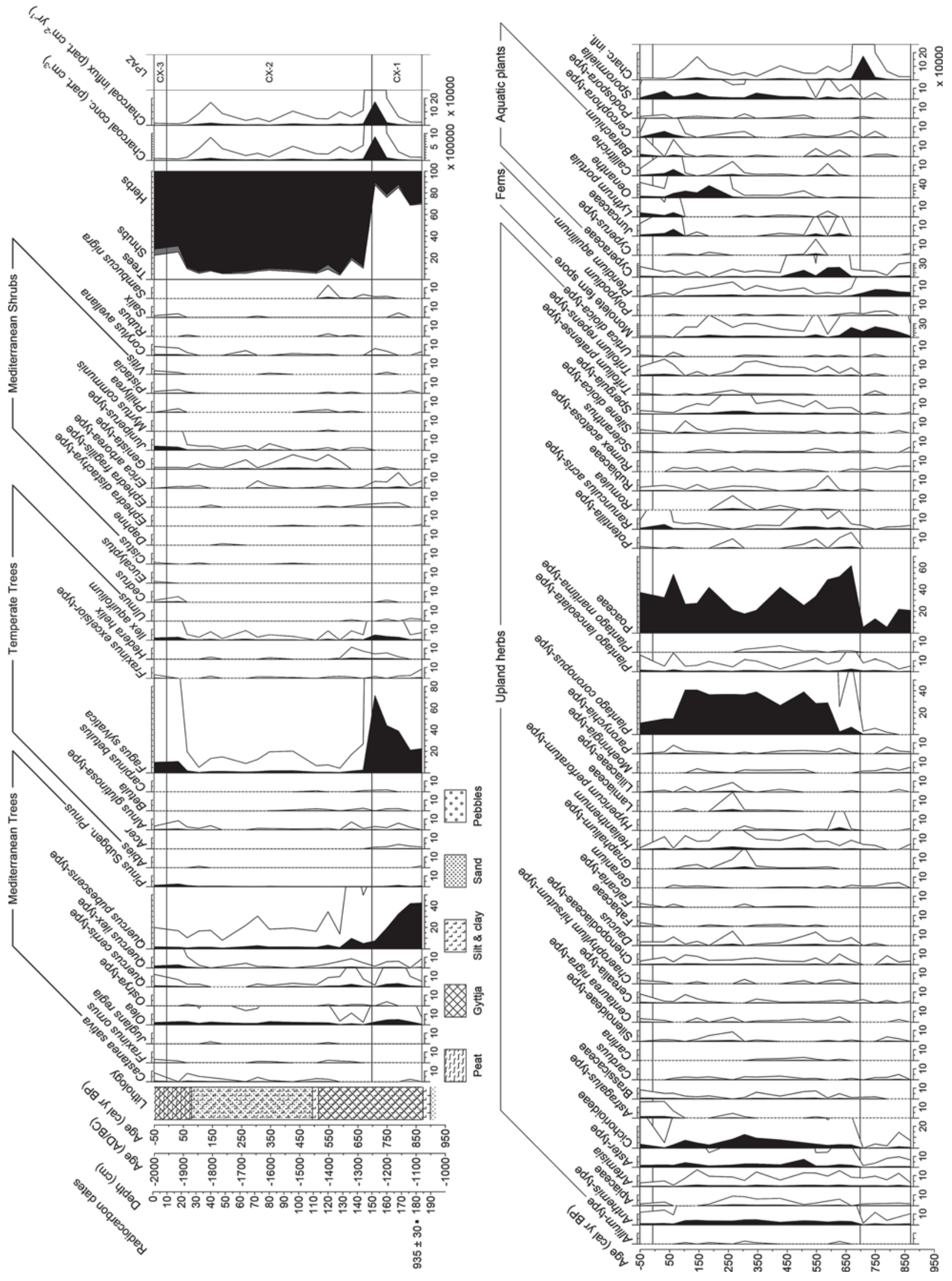
4Fig. 5 Marcato Cixé, arboreal and non-arboreal pollen percentage and charcoal diagram. Aquatic plants and spores are excluded from pollen sum. Analysts: J.F.N. van Leeuwen, E. Vescovi

displaced the original forest vegetation and most open lands during the past 100 years. The relevance of this most recent vegetational shift is underscored by a separate, statistically significant zone (GL-6).

Microscopic charcoal suggests that regional fire activity was particularly low before ca. 3,000 cal вP (ca. 1000 BC). Open habitats were gained by the use of fire, which culminated at the onset of forest collapses (sequence peak at ca. $850 \mathrm{cal} \mathrm{BP,} \mathrm{AD} \mathrm{1100,} \mathrm{Fig.} \mathrm{4).} \mathrm{Aquatic} \mathrm{vegetation}$ varied conspicuously throughout the entire record, in particular in association with land use and forestry shifts (e.g. decline of Potamogeton-type during GL-3, expansions of Pediastrum during GL-4, Ceratophyllum during GL-5 and Lemnaceae during GL-6), suggesting that lakelevels and/or eutrophication shifts were closely linked to land use.

\section{Marcato Cixé}

About $400 \mathrm{~m}$ higher and $60 \mathrm{~km}$ east of Gorgo Tondo and Gorgo Lungo, dense beech-oak forests rich in Ilex aquifolium were growing at Marcato Cixé during LPAZ CX-1 (850-700 cal BP, AD 1100-1250, Fig. 5). At around 1,250 cal вр, Fagus sylvatica $(>70 \%)$ had almost completely replaced $Q$. pubescens, suggesting a succession towards dark oro-mediterranean beech-holly forests (AP ca. $90 \%)$. At the transition to zone CX-2 (700-0 cal BP, AD 1250-1950), microscopic charcoal-inferred regional fire activity peaked. Less than 100 years later, beech-holly forests had totally collapsed (Fagus $<2 \%$, Ilex $<1 \%$ ), giving way to very open grasslands with a dominance of Plantago coronopus-type and Poaceae and important shares of Cichorioideae, Aster-type, Anthemis-type, Helianthemum, Spergula, and Trifolium repens-type. Increased fire activity, the expansion of grassland and the abundance of dung-related fungi such as Sporormiella (followed by Cercophora and Podospora) suggest that anthropogenic burning and strong pastoral activities were the main cause of the beech-holly forest collapse. Oromediterranean beech-holly forests have partially recovered during recent years (CX-3, AD 1950-2000), although the landscape has remained rather open (heliophilous Juniperus-t., NAP > $70 \%$ ).

\section{Urgo Pietra Giordano}

In close proximity of Marcato Cixé but about $120 \mathrm{~m}$ higher in altitude, Urgo Pietra Giordano provides a longer palynological record covering the past 7,000 years and thus reaching back to the Mid Holocene and the Neolithic. Equal shares of AP and NAP shifting to $>80 \%$ AP during zone PG-1 (7,000-5,650 cal BP, 5050-3700 BC; Fig. 6) suggest that vegetation was initially rather open but became gradually more closed. During subzone PG-1a (7,000-6,650 cal BP, 5050-4700 вC), deciduous oaks (20-40\% Quercus pubescens-type including Q. petraea, 1-10\% Q. cerris-type) dominated in the forest vegetation together with Fagus sylvatica (10-30 \%) and Ilex aquifolium (1-2\%). Open land vegetation was dominated by Poaceae, Cichorioideae and diverse herbs (e.g. Aster-type, Achillea-type, Artemisia, Carduus, Hypericum perforatumtype, Potentilla-type, Rumex acetosa-type, Silenoideae). Low Cerealia-type, Plantago lanceolata-type, Daucus carota, Urtica dioica and Rumex acetosella-type pollen percentages may point to weak middle Neolithic land use in the area.

At the transition to zone PG-1b $(6,650-5,650$ cal BP, 4700-3700 BC), forests abruptly closed (AP 90\%) displacing grasslands, and Fagus sylvatica became by far the most important species $(>70 \%)$, forming mesophilous beech forests with Ilex aquifolium. Only ca. 100 years later, Fagus sylvatica and Ilex aquifolium declined, to recover at $6,500 \mathrm{cal} \mathrm{BP}(4550 \mathrm{BC})$. Beech-holly forests dominated for 300 years but then re-collapsed at ca. 6,200 (4250 BC). Both Fagus sylvatica and Ilex aquifolium declines at ca. 6,550 and 6,200 cal вP (4600 and 4250 вс) were associated with increases of Quercus pubescens-type, but only the first decline was associated with an expansion of open land (e.g. Poaceae, Asteroideae, Achillea-type, Cerealia-type, Plantago lanceolata-type, Daucus carota), whereas forests remained closed during the second decline (AP 80-90\%). The second temporary shift from oromediterranean (beech-dominated) to supramediterranean (deciduous oak-dominated) vegetation may thus have other causes than human impact, for instance a shift to warmer and/or drier climate. About 500 years after this shift, Fagus sylvatica and Ilex aquifolium re-expanded at ca. 5,800 cal вP (3850 вC). Subsequently, beech-holly forests remained stable for more than a millennium (PG-2a, 5,750-4,500 cal BP, 3800-2550 BC). The local dominance of Fagus sylvatica around the site is well documented in the overview macrofossil record (Fig. 7). During this time of low disturbance, Abies nebrodensis was probably growing in the area, though in small numbers (continuous curve in PG-2).

Beech-holly forests were opened at the onset of the Bronze Age (Leighton 1999) at 4,500-4,150 cal вP (2550-2200 вс, PG-2b). Further massive openings of these forests occurred during the Early Bronze Age at 4,1503,650 cal вP (2200-1700 BC, PG-3a), when holly stands were almost completely destroyed. This forest disruption phase also affected Abies nebrodensis and other trees such 

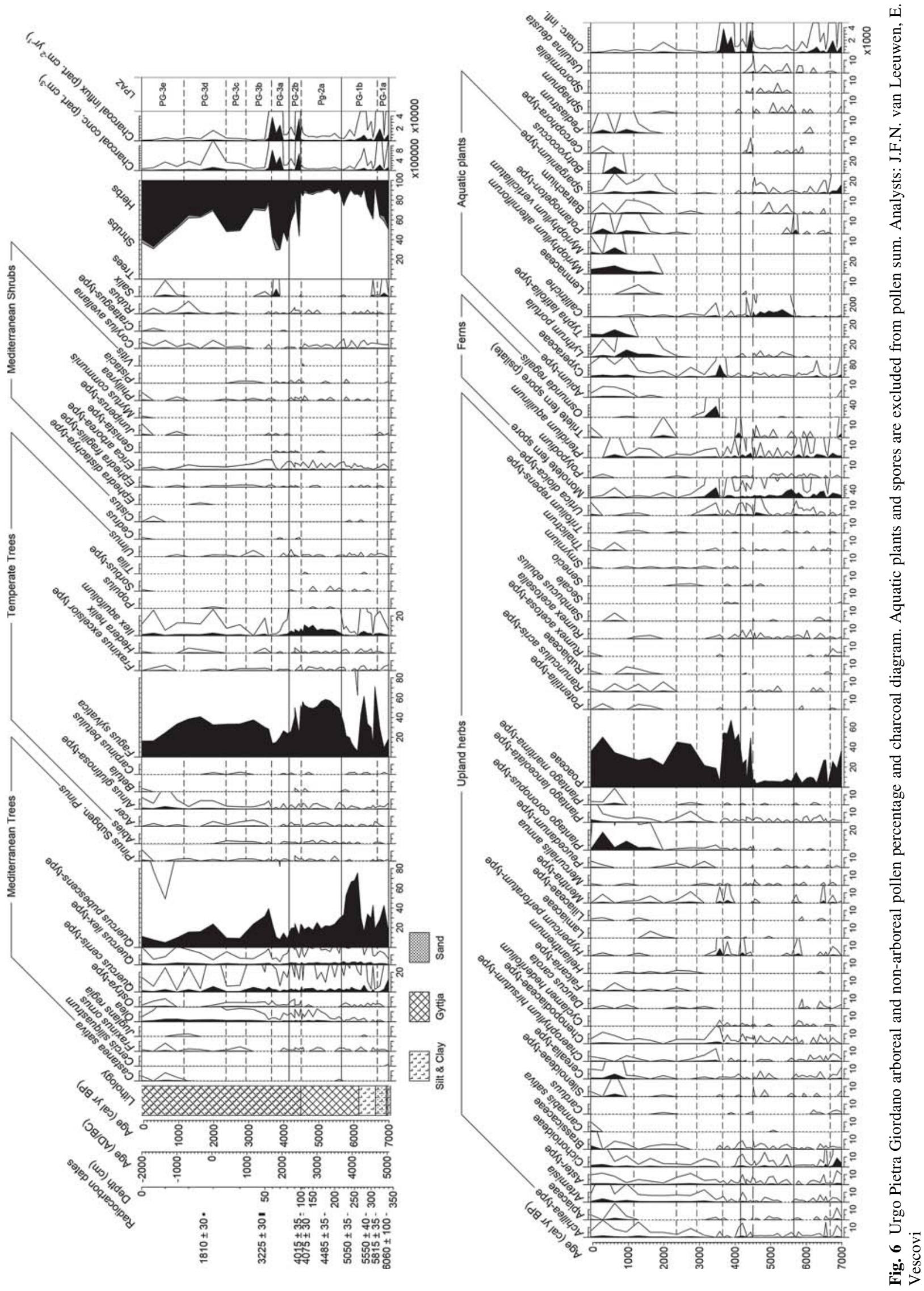
as Acer (interrupted curves). The two forest destruction phases (PG-2b, PG-3a) were strongly linked to the establishment of grasslands (Poaceae dominance) and burning (maximum of microscopic charcoal, Fig. 6). Afterwards, beech forests partly recovered (AP 70-80\%), in an initial successional phase that lasted ca. 200 years, with abundant Q. pubescens-type (PG-3b, 3,650-2,950 cal BP, 1700-1000 $\mathrm{BC})$. During this phase of forest recovery, Abies nebrodensis probably re-established locally for the last time. Forest abundance decreased (AP ca. 50\%) at 2,950-2,350 cal вР (1000-400 BC, PG-3c) and during the past 1,200 years (AD 800-2000, PG-3e). The most recent expansion of open land was connected to strong intensification of land use, mainly arable and pastoral farming as evidenced by marked increases in e.g. Cerealia-type, Artemisia, Cichorioideae, Plantago coronopus-type, $P$. lanceolata-type and P. maritima-type. This land use phase also caused major water-level changes (mass expansions of e.g. Typha latifolia-type, Myriophyllum alternifolium, $M$. verticillatum, Potamogeton-type, Sparganium-type, Pediastrum) which ended with the partial destruction of the pond by dredging and its conversion into a diked mire for reliable water supply. Overall, numerical zonation results indicate that vegetation composition remained relatively stable during the past 4,200 years (PG-3). During this long period, beech forests rich in deciduous oaks and holly prevailed, suggesting rather stable oro-mediterranean vegetational conditions during the late Holocene.

\section{Gorgo Pollicino}

Pollen data suggest that very open grasslands prevailed throughout the past millennia (Fig. 8). This contrasts with data from other sites in the mountains of Northern Sicily (e.g. Urgo Pietra Giordano at comparable altitudes and only $3 \mathrm{~km}$ away), where the complete or nearly complete absence of forests in the mountains of Northern Sicily occurs only very rarely (Figs. 3, 4, 5, 6). An explanation for the difference may lie in the finding that only at Gorgo Pollicino sandy sediments prevail virtually throughout (380-132 cm, Table 3; Fig. 8). This sand may have originated from eroded topsoils containing pollen from pastures directly around the lake which may have masked the extralocal vegetational signal. Nevertheless, the pollen signal of Pollicino may still be used to interpret very local agricultural activities, because the four statistically significant LPAZ GP-1 to GP-4, provide evidence that the sediment was not uniformly reworked. While grasslands dominated by Poaceae, Cichorioideae, Plantago coronopus-type, and Centaurea nigra-type probably occurred at ca. 3,600-2,600 cal вР (1650-650 вс) and 2,100-1,200 cal вР (150 BC-AD 750), meadow communities of Anthemis-type, Trifolium repens-type, Plantago coronopus-type and Carlina were important at ca. 2,600-2,100 cal BP (650-150 BC). However we cannot completely exclude that this pollen reflects un-reworked extra-local vegetation. In this case, the open Bronze and Iron Age environments around Gorgo Pollicino would represent a regional vegetational anomaly, perhaps explained by favourable local conditions for pastoral farming and related regular burning (see high Sporormiella, Podospora, Cercophora and microscopic charcoal values). The palynological evidence becomes more reliable in the autochthonous organic sediments of the past ca. 1,300 years. In the few tree stands growing around Gorgo Pollicino, Castanea sativa and Quercus pubescens-type were important, whereas the weak pollen

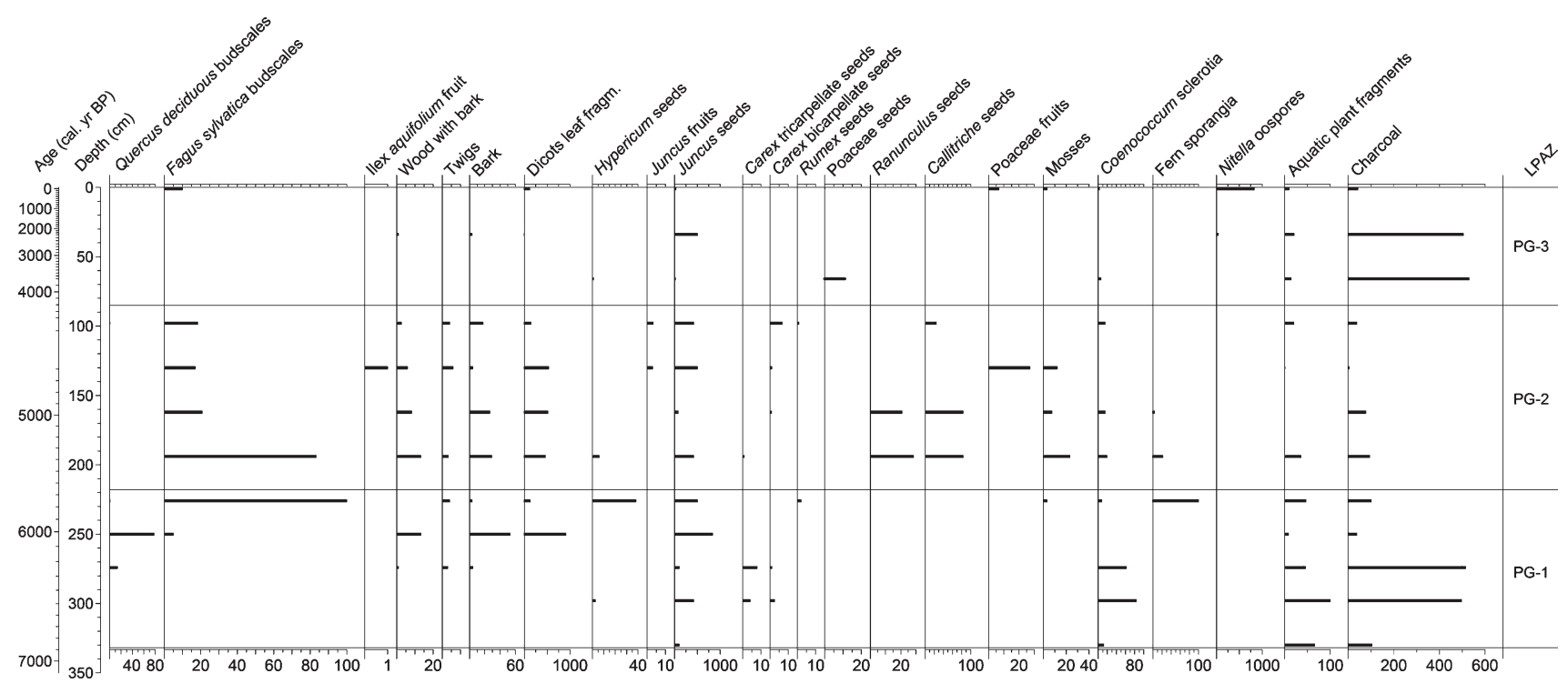

Fig. 7 Urgo Pietra Giordano macrofossil concentration diagram. Macrofossils are shown as numbers per $10 \mathrm{~cm}^{3}$ of sediment volume. Analysts: B. Gnaegi, E. Vescovi 

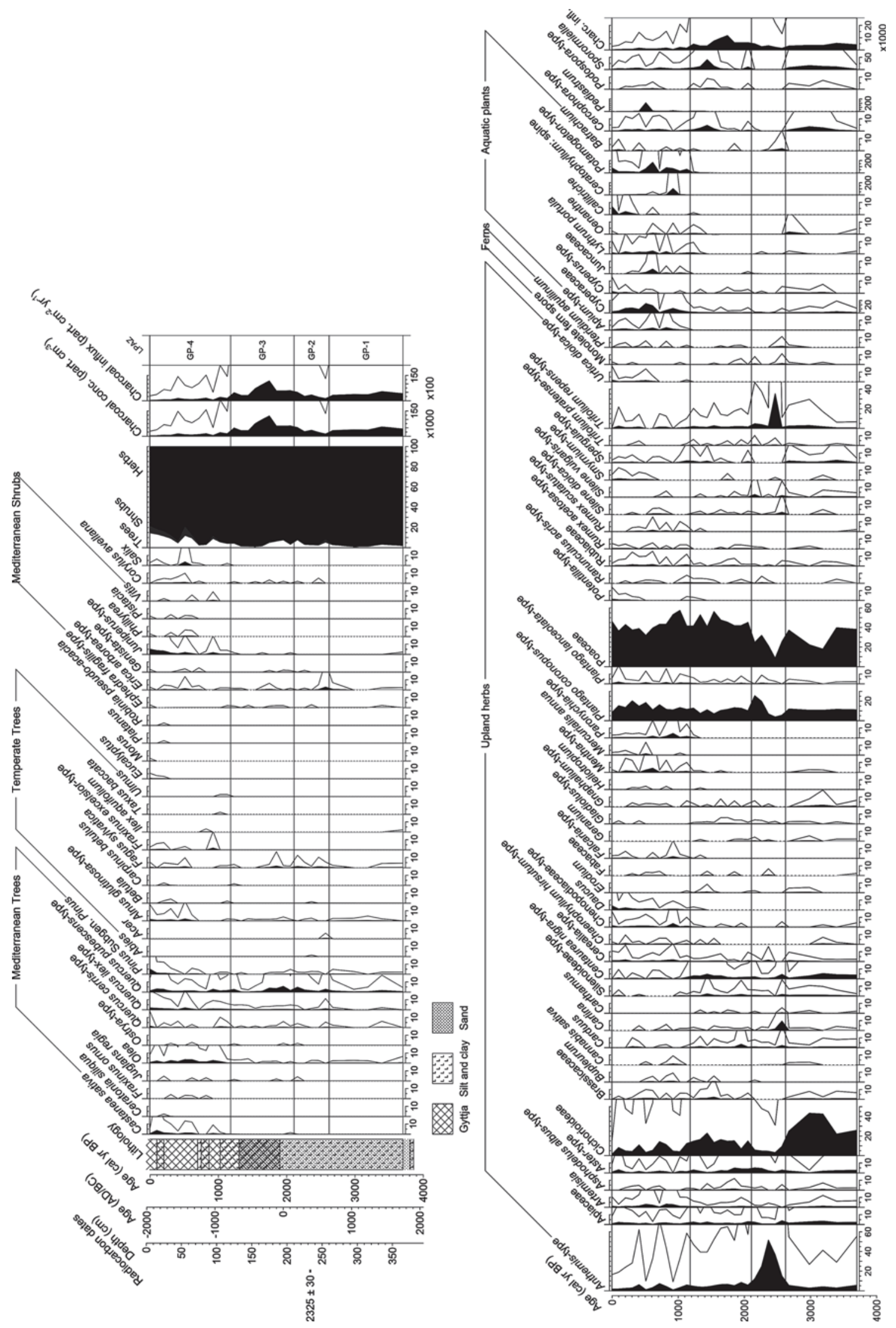

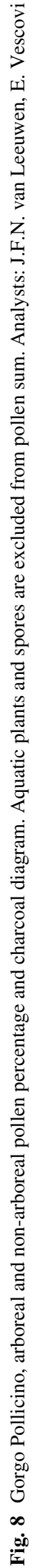


imprint of evergreen broadleaved trees such as Olea and $Q$. ilex may have primarily derived from lowland vegetation (GP-4). NAP reaching 80-90\% suggests that grasslands prevailed (Poaceae, Plantago coronopus-type, Cichorioideae), while pollen of aquatic plants such as Potamogeton-type documents the presence of water-plant communities.

\section{Discussion}

\section{Vegetation structure and composition during periods of low land use}

The palaeobotanical records from the mountains of Northern Sicily suggest that closed forests dominated the landscape during periods of low human impact. Deciduous broadleaved trees (Quercus pubescens, Q. cerris and Ulmus) grew together with evergreen broadleaved trees or lianas (e.g. Q. ilex, Q. suber, Hedera helix) around the meso-mediterranean sites Gorgo Tondo and Gorgo Lungo. In the supra-mediterranean belt above the meso-mediterranean belt, forests were dominated by deciduous broadleaved oaks (Q. cerris, $Q$. pubescens; Bisculm et al. 2012). At higher altitudes, at the transition between the supramediterranean and oro-mediterranean belts, Fagus sylvatica, Quercus pubescens, Q. petraea, Q. cerris and Ilex aquifolium formed beech-dominated forests at Marcato Cixé and Urgo Pietra Giordano. Abies nebrodensis played no role at our sites, though it was most likely present around Urgo Pietra Giordano until ca. 2,000 years ago (closed pollen curve). Indeed, a previous study reports findings of Abies nebrodensis and A. alba wood in the sediments of Urgo Pietra Giordano (Bertolani Marchetti et al. 1984). Whereas our results are in biostratigraphic agreement with the study of Bertolani Marchetti et al. (1984) from the same site, striking differences exist in the chronology. In the earlier study, wood at a sediment depth of $150 \mathrm{~cm}$ provided an uncalibrated radiocarbon age of $9,200 \pm 90$ BP. This date falls in a Fagus peak of $>40 \%$, which is also present at the same depth in our pollen record, where it is chronologically constrained by three radiocarbon dates of 4,000-5,000 uncal BP (Fig. 6). The Urgo Pietra Giordano pollen record of Bertolani Marchetti et al. (1984) does not cover sediments deeper than $245 \mathrm{~cm}$ (or older than ca. 6,000 years), which explains why high abundances of Quercus pubescens-type (peak >70\%) are missing at base of their profile (zone PG-1, Fig. 6).

\section{Vegetation changes in response to land use}

Grasslands and meadows have a long history in the mountains of Northern Sicily. At the study site Urgo Pietra
Giordano, the oldest evidence for widespread grasslands (NAP $50 \%$, Poaceae, Cichorioideae, Achillea-type, Astertype) reaches back to ca. 7,000-6,500 years ago, and thus to the Middle Neolithic period. We cannot assess how open or closed forests were before that time, because our records do not cover those periods. The only other available record from the mountains of Northern Sicily, Urio Quattrocchi (Figs. 1, 9), shows that at 7,000-6,500 cal BP (5050-4550 $\mathrm{BC}$ ), open land (NAP $>80 \%$ ) had become established in a previously densely forested area (Bisculm et al. 2012, AP 70-90\%). Numeric analyses (e.g. RDA, redundancy analysis) on a continuous high-resolution time series of 500 years $(6,820-6,320$ cal BP, 28 year/sample) from Urio Quattrocchi show that fire impact, most likely of human origin (significant correlation with human indicators such as Cerealia-type), was significantly related to forest disruption (explaining ca. $22 \%$ of vegetational variance). Given that at our site, Urgo Pietra Giordano, the occurrence of open-land vegetation at 7,000-6,500 cal вP (5050-4550 BC) was also associated with increased fire and land-use activities (Figs. 6, 9), open-land vegetation probably reflects a first widespread landnam of mountain areas by middle Neolithic Sicilian cultures. The oldest unambiguous evidence of Neolithic crop cultivation is dated to 5711-5558 BC at Uzzo Cave in coastal Northern Sicily and comprises macrobotanical remains of Triticum monococcum, T. dicoccum, T. aestivum, T. compactum, Lens culinaris, Ficus carica, Hordeum vulgare, Vicia faba, Pisum, Prunus amygdalus and wild Olea europaea (Leighton 1999). Archaeologists assume that the most favorable areas of Sicily for Early Neolithic farming were the southern and eastern coastal plains, whose light, fertile soils are particularly suited for cereal cultivation. Indeed, at Gorgo Basso in the coastal plains of southern Sicily a massive Neolithic cereal-fig based cultural phase already occurred at 5500-5000 BC, ca. 500 years before first evidence from Urio Quattrocchi and Urgo Pietra Giordano at 5000-4500 BC. In best agreement with our interpretation, archaeological evidence documents that by $5000 \mathrm{BC}$ farming had spread from the fertile coast to the hilly country of central Sicily (Leighton 1999).

Our new sites and the previously published Urio-Quattrocchi (Bisculm et al. 2012; Fig. 9) show a remarkable agreement of forest and open land phases. Synchronous phases of grassland establishment occurred at the Late Copper/Early Bronze Age transition (around 4,500 cal BP, $2550 \mathrm{BC}$ ), during the Early Bronze Age (4,200-3,800 cal вP, $2250-1850 \mathrm{BC})$, the Early Iron age (2,800-2,600 cal BP, $850-650$ BC) and the Medieval Time (800-700 cal BP, AD 1150-1250; Fig. 9). Coeval pulses of land use intensification may reflect complex interactions between cultural innovations (e.g. introduction of metal tools during the Bronze and Iron Ages) and climate oscillations, which 
Table 3 Lithology of sites

\begin{tabular}{|c|c|c|c|c|c|}
\hline Site & Depth (cm) & Sediment & Site & Depth (cm) & Sediment \\
\hline \multirow[t]{6}{*}{ Gorgo Tondo } & $0-50$ & Silty clay gyttja & Marcato Cixé & $12-26$ & Peaty gyttja \\
\hline & $50-244$ & Gyttja & & $26-107$ & Clay, sand, pebbles \\
\hline & $244-310$ & Sandy gyttja & & $107-111$ & Clay \\
\hline & $310-365$ & Sand with gyttja & & $111-181$ & Clayey gyttja \\
\hline & $365-395$ & Sand & & $181-186$ & Silty clay \\
\hline & $395-400$ & Sand with gyttja & & $186-190$ & Sand, pebbles \\
\hline \multirow[t]{27}{*}{ Gorgo Lungo } & $0-283$ & Gyttja & Gorgo Pollicino & $0-15$ & Gyttja \\
\hline & $283-291$ & Silt/Silty gyttja & & $15-25$ & Silt with gyttja \\
\hline & $291-300$ & Silty gyttja & & $25-73$ & Gyttja \\
\hline & $300-320$ & Sandy silt & & $73-78$ & Silt \\
\hline & $320-338$ & Sand & & $78-89$ & Silty gyttja \\
\hline & $338-403$ & Silty gyttja & & $89-105$ & Gyttja \\
\hline & $403-414$ & Silt & & $105-132$ & Silty gyttja \\
\hline & $414-445$ & Gyttja & & $132-190$ & Sandy silty gyttja \\
\hline & $445-460$ & Silty gyttja & & $190-342$ & Sandy silt \\
\hline & $460-470$ & Gyttja & & $342-365$ & Silty sand \\
\hline & $470-482$ & Silty gyttja & & $365-375$ & Sand \\
\hline & $482-495$ & Gyttja & & $375-380$ & Clay sand \\
\hline & $495-498$ & Sandy silt & & 380 & Clay \\
\hline & $498-515$ & Silty gyttja & Urgo Pietra Giordano & $0-29$ & Clayey silty gyttja \\
\hline & $515-528$ & Silt & & 29-99 & Silty gyttja \\
\hline & $528-531$ & Gyttja & & $99-264$ & Gyttja \\
\hline & $531-535$ & Wood & & $264-317$ & Silt, Sand \\
\hline & $535-537$ & Sandy silt & & $317-335$ & Silty sand \\
\hline & $537-553$ & Gyttja & & $335-338$ & Silty gyttja, pebbles \\
\hline & $553-578$ & Clay-silt & & 338-339 & Silty sand \\
\hline & $578-663$ & Gyttja & & $339-343$ & Silt \\
\hline & $663-682$ & Sandy gyttja & & $343-344$ & Silty sand \\
\hline & $682-694$ & Gyttja & & & \\
\hline & $694-708$ & Sand & & & \\
\hline & $708-709$ & Gyttja & & & \\
\hline & $709-722$ & Sand & & & \\
\hline & $722-737$ & Sandy gyttja & & & \\
\hline
\end{tabular}

primarily controlled yields and thus human population densities (e.g. Maise 1998; Wirtz and Lemmen 2003; Tinner et al. 2003, 2009; Büntgen et al. 2011; Sadori et al. 2015). However, the palynological evidence suggests that cereal production was not prominent at the mountain sites of Northern Sicily; instead pastoral activities were important. Humanized grasslands were very species rich, as observed elsewhere in southern and central Europe including lowland Sicily (Colombaroli and Tinner 2013).

\section{The role of climate}

It is difficult to disentangle climatic and human effects on Mediterranean vegetation. One possibility for solving this problem is to check vegetational conditions just before the onset of intense land use (i.e. the Neolithic period at ca. 6000 вC). In addition, palynological records may provide direct evidence of land use such as pollen and spores of crops, weeds and coprophilous fungi. In any case, only non-pollen evidence of climate change should be considered to avoid circular reasoning. Pollen-independent palaeoclimatic evidence is very scarce in Sicily (Magny et al. 2011) and some of the available data are only fragmentary (Frisia et al. 2006). Sea-surface temperature reconstructions from the Sicilian Sea (Cacho et al. 2001; Marchal et al. 2002) suggest a warm mid Holocene (ca. 8,000-5,000 cal BP) and a subsequent cooling in the Late Holocene (ca. past 5,000 years). This pattern is in 


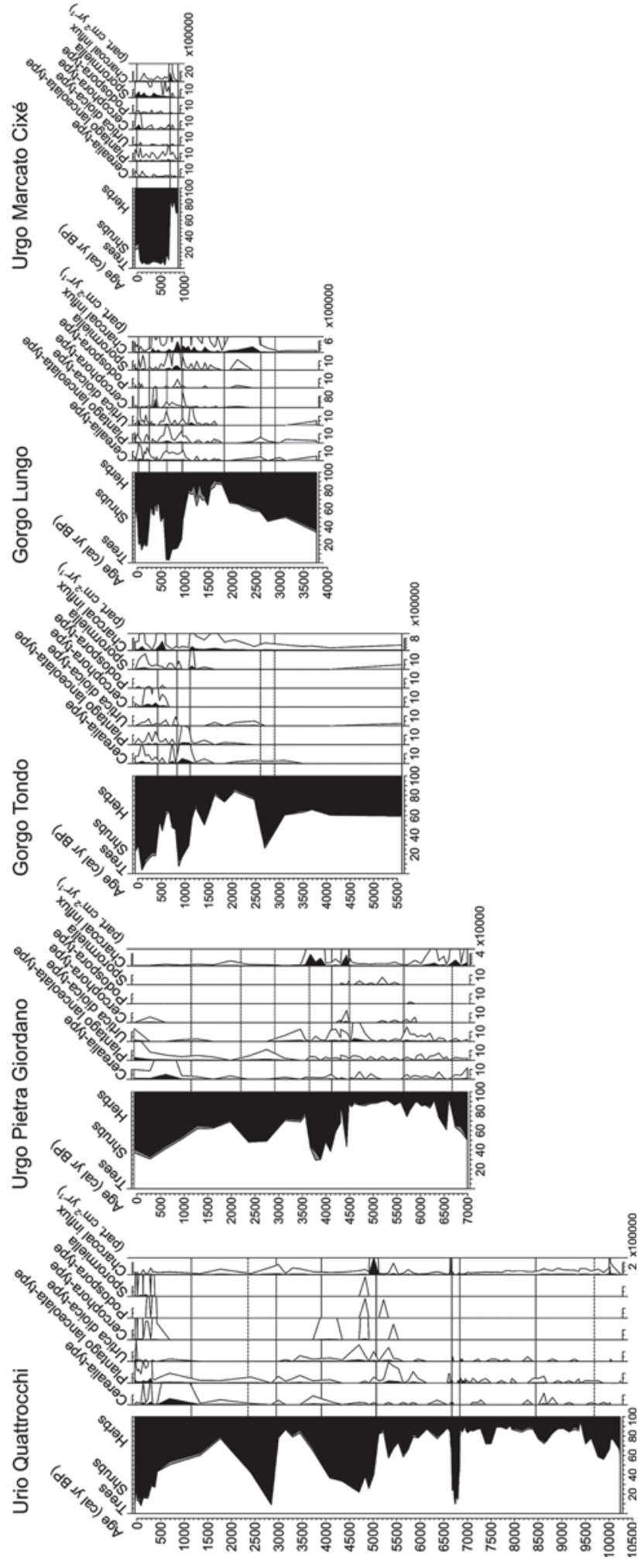

Fig. 9 Comparison of Sicilian Sicani, Nebrodi and Madonie mountain sites including Urio Quattrocchi (Bisculm et al. 2012). Gorgo Pollicino is not shown because we assume substantial reworking (weathered sandy soil material dominates the sediment) agreement with other Mediterranean palaeoclimatic records including glacier oscillations from southern Italy (Abrantes et al. 2012), which suggest that mid Holocene summer temperatures were ca. $1-3{ }^{\circ} \mathrm{C}$ warmer than today. Similarly, climate models suggest warmer-than-today mid Holocene summer temperatures in southern Italy, while winters were probably slightly cooler (e.g. Brayshaw et al. 2011; Tinner et al. 2013).

Lake-levels at Lago Preola in Sicily (Fig. 1) were high during the mid-Holocene and declined at 4,500 cal BP, suggesting that moisture availability was lower during the Late Holocene (Magny et al. 2011). This agrees well with other Mediterranean lake-level studies south of $40^{\circ} \mathrm{N}$, but contrasts with lake-level reconstructions in the Mediterranean north of $40^{\circ} \mathrm{N}$ that suggest increasing late Holocene humidity (Magny et al. 2012). Lake-levels at Lago Preola declined rather abruptly at the onset of the Bronze Age (2500 BC; Leighton 1999), when land use activity intensified at our sites and elsewhere in Sicily, including the Lago Preola area (Noti et al. 2009; Calò et al. 2012). Palaeoecological signals of increased arable and pastoral farming are supported by ample archaeological evidence of increasingly sophisticated architecture during the Early Bronze Age, such as turreted stone walls for residential or defense purposes as well as funerary landscapes with large rock-cut tombs, rich in porticoes and carved facades. These developments not only document the technological mastery of the Early Bronze Age societies (Leighton 1999), such proto-urban Sicilian features also provide evidence for increased wealth, and thus yields, in an agricultural economy. Alternatively to climatic causes, low lake-levels at and after $2500 \mathrm{BC}$ may therefore document the onset of water use by farmers and villagers for irrigation, handcraft and civil purposes during the dry summer season. Despite these uncertainties it is clear that late Holocene conditions always remained humid enough to support the persistence of mesophilous vegetation types such as beech forests in the mountains of Northern Sicily. The late Holocene trend to less humid conditions, if real, did not have a detectable impact on beech forests, which largely maintained their Sicilian mid Holocene range. For instance the only major replacement of mesophilous Fagus sylvatica by more drought-adapted Quercus pubescens-type at Urgo Pietra Giordano occurred about 6,000 years ago (4250 BC), when the climate was warm but particularly moist according to lake-level records (Magny et al. 2011). Yet, it might be argued that aridity pulses may have temporarily destroyed the beech forests, allowing more intense land use. This hypothesis can be rejected for the past 1,000 years. The opening of the forests during Medieval 
and Modern times (ca. 600-100 years ago; Fig. 9) occurred during the Little Ice Age, when the prevailing conditions were predominantly cool and wet in Sicily and southern Italy (see discussion in Calò et al. 2013). Similarly, the premedieval forest openings cannot be explained by aridity crises, given that drought significantly reduces agricultural yields in the Mediterranean area (Allen 2001), and our data document expanded agricultural activity. In addition, aridity spells should have caused rapid vegetation composition changes towards more drought-adapted communities (e.g. co-occurring oaks), which are also absent in our records. However, to address this question more carefully, multiproxy studies with high temporal precision (avoiding bulk dating) and decadal resolution would be needed (Pérez-Sanz et al. 2013; Ammann et al. 2000, 2014; Tinner et al. 2015). Taken together, the survival of mesophilous forests over the last several millennia argues for a strong resilience of today's oro-mediterranean stands to repeated combined climatic and human impacts, even if their persistence was probably facilitated by the late Holocene climatic trend toward cooler (and perhaps moister) summers (Calò et al. 2012; Tinner et al. 2013).

\section{What is natural?}

Similarities between our records and Urio Quattrocchi, a mountain site that includes pre-agricultural times, argue that vegetational conditions during periods of low human impact can be used to assess natural conditions. Considering the climatic development during the past millennia, today's forest types would likely include mixed deciduous oak-forests with a substantial share of evergreen broadleaved trees in the upper meso-mediterranean belt (Gorgo Tondo, Gorgo Lungo), mixed deciduous-oak forests in the supramediterranean vegetation belt (Urio Quattrocchi) and beech-holly forests in the oro-mediterranean belt (Marcato Cixé, Urgo Pietra Giordano). These results add to palaeobotanical evidence from the hills of inland Sicily (Pergusa, e.g. Sadori and Narcisi 2001), coastal Sicily (Gorgo Basso, Lago Preola, Biviere di Gela; Noti et al. 2009; Tinner et al. 2009; Calò et al. 2012) and the circumSicilian islets (Pantelleria, Calò et al. 2013), which suggests that in the absence of land use, the humid to subhumid ecosystems of Sicily (Fig. 1) would be forested. This finding agrees very well with palaeobotanical evidence from elsewhere in Europe including the Mediterranean realm, suggesting that under natural conditions the continent would be predominantly forested (Davis et al. 2015). In Sicily, rather dense Mediterranean forests would prevail from the thermo-mediterranean (evergreen broadleaved) to the oro-mediterranean (deciduous broadleaved) belt, perhaps with the exception of the southeastern coast, where annual mean precipitation falls below $400 \mathrm{~mm}$ (Noti et al. 2009). For this hottest and driest area of Sicily, palaeoecological evidence suggests the occurrence of a mosaic of open evergreen broadleaved forests, shrublands and grasslands dominated by Quercus ilex, $Q$. coccifera, $Q$. suber, Olea europaea, Chamaerops humilis, Juniperus, Pistacia lentiscus, Poaceae, Cichorioideae, Chenopodiaceae, Achillea, Rumex, Artemisia and Plantago. Our Sicilian vegetation assessment is in contrast with the "aridification hypothesis" which attributes today's widespread unforested grassland and maquis spaces primarily to (too) dry late Holocene climates. This hypothesis assumes no additional resilience capacity of forest vegetation in the case of a further shift to drier conditions. Instead, in agreement with modern vegetation ecologists (e.g. Maugeri and Leonardi 1974; Di Benedetto et al. 1984; Federici and Mangialardi 1995; Cullotta and Pasta 2004), we attribute today's open spaces to land-use practices over millennia, which created a seeming xerophytization (Muller et al. 2015), by promoting garrigue, maquis and xeric grassland vegetation at the expenses of forests (Fig. 2). This interpretation is supported by recent modelling results suggesting that in the absence of human impact, even the warmest and driest areas of Sicily would be forested (Henne et al. 2015). Thus, xerophytic open land vegetation types are in equilibrium with land use practices of the past centuries but in disequilibrium with the current humid to sub-humid Sicilian climate. For this reason numeric pollen reconstructions of climate conditions (e.g. temperatures, precipitation) relying on the climate-equilibrium assumption have to be taken with due care, particularly if they are in contrast with other palaeoclimatic evidence (Howe and Webb 1983; Seppä et al. 2004; Finsinger et al. 2010; Abrantes et al. 2012; Luterbacher et al. 2012).

At all sites in the mountains of Northern Sicily, fire occurrence was strongly linked to the creation of open land and cultural indicators. Thus, our results support earlier studies, which emphasize that since Neolithic times, and particularly in the metal ages and later, forest-replacing fires were closely related to agricultural activities (Noti et al. 2009; Tinner et al. 2009; Bisculm et al. 2012; Calò et al. 2012, 2013; Sadori et al. 2015). Forested habitats were not fire-prone, very much in contrast to flammable natural grassland, garrigues and maquis, which thrived during the dry periods of the early Holocene and the early mid Holocene before ca. 8,000-7,000 cal yr BP (ca. 6000-5000 BC; Tinner et al. 2009). Taken together, palaeoecological records provide evidence that both climate change and human impact can lead to the creation of flammable vegetation types, that once established, may contribute to maintain fire activity high. 


\section{Conclusions}

New palaeoecological sites from the mountains of Northern Sicily allow us to gain novel insights into the vegetation and fire history of Sicily. Some of the remnant forests of the island have a millennial long history (e.g. Urgo Pietra Giordano). In some cases such as in the Ficuzza area (Gorgo Tondo and Gorgo Lungo) the original vegetation was only recently partially displaced by afforestation with locally exotic tree species, while in other cases grasslands and meadows have replaced forest vegetation (e.g. Marcato Cixé). Fire has been used since the Neolithic to manage open spaces and to keep the vegetational succession at an early non-arboreal stage. However, forest vegetation was very resilient and periods of forest recovery occurred up to historical times, if land use ceased. There is no evidence that mesophilous vegetation was more widespread than today during the mid and late Holocene, which argues against significant moisture impacts (e.g. "aridification") during the past millennia. The absence of range reductions of Fagus sylvatica and Ilex aquifolium since the mid Holocene, when climate was $1-3{ }^{\circ} \mathrm{C}$ warmer than today, signifies that mesophilous forest vegetation may persist in Sicily in situ under moderate global-warming, if the climate does not become too dry. Fagus sylvatica populations at the southern edge of their European distribution range, such as those from the mountains of Northern Sicily, developed under warm and very dry summer conditions. While a very few Central European beech forests grow under conditions as warm as in Sicily (Ellenberg 2009; Czucz et al. 2011), adaptations to extremely dry summer season conditions are unique to southern European Fagus sylvatica populations. They may thus be particularly suited to provide heat and drought-adapted ecotypes for maintaining Central European forest vegetation, in which Fagus sylvatica plays a paramount role today (Ellenberg 2009), under global warming conditions. Moreover, genetic data suggest that Sicilian beech forests were, and are, a principal reservoir of Fagus sylvatica genetic richness (Demesure et al. 1996; Hewitt 1999; Médail and Diadema 2009), which may enable resilient responses or adjustments to environmental change. However, anticipating future climate change impacts requires a thorough combination of ecological and palaeoecological evidence with dynamic landscape and vegetation modelling. Recent estimates by palaeoecologically validated dynamic models are available for lowland vegetation (Henne et al. 2015) but are lacking for the mountain communities of Sicily. This gap is crucial as much of the biodiversity of Sicily is located in mountainous areas. Climate warming may trigger upslope migration of species within the next decades and centuries as shown by examples from the Alps (e.g. Schwörer et al.
2014), but it is presently unclear whether the mountains of Sicily have sufficient altitude and habitat variety to support local survival of species, if climate should become significantly warmer $\left(>2{ }^{\circ} \mathrm{C}\right)$.

Acknowledgments We thank Willi Tanner for technical advice during the coring and Florencia Oberli for palynological sample preparation, Brigitta Ammann for her steady support, Tomasz Goslar for radiocarbon dating, Walter Finsinger, Todd J. Hawbaker, Robert $\mathrm{S}$. Thompson, and an anonymous reviewer for valuable comments on the manuscript. WT is grateful to the Swiss National Science Foundation for supporting this study (SNF PP00P2-114886) and CMM acknowledges the Swiss Government Excellence Postdoctoral Scholarship (2014.0386). Any use of trade, firm, or product names is for descriptive purposes only and does not imply endorsement by the U.S. Government.

\section{References}

Abrantes F, Voelker AHL, Sierro FJ, Naughton F, Rodrigues T, Cacho I, Ariztegui D, Brayshaw D, Sicre M-A, Batista L (2012) Paleoclimate variability in the Mediterranean Region. In: Lionello P (ed) The climate of the Mediterranean region-from the past to the future. Elsevier, Amsterdam, pp 1-86

Allen HD (2001) Mediterranean Ecogeography. Pearson Education, Harlow

Ammann B, Birks HJB, Brooks SJ, Eicher U, Von Grafenstein U, Hofmann W, Lemdahl G, Schwander J, Tobolski K, Wick L (2000) Quantification of biotic responses to rapid climatic changes around the Younger Dryas-a synthesis. Palaeogeogr Palaeoclimatol Palaeoecol 159:313-347

Ammann B, Van Raden UJ, Schwander J et al (2014) Responses to rapid warming at Termination la at Gerzensee (Central Europe): primary succession, albedo, soils, lake development, and ecological interactions. Palaeogeogr Palaeoclimatol Palaeoecol 401:183-184

Baldi M, Crisci A, Genesio L, Piani F, Meneguzzo F, Dalu GA, El Asmar T (2004) Remote climate processes underlying summer drought events in the Mediterranean. In: Balwois conference 2004. Ohrid, FY Republic of Macedonia, pp 1-12

Bazan G, Marino P, Guarino R, Domina G, Schicchi R (2015) Bioclimatology and vegetation series in Sicily: a geostatistical approach. Ann Bot Fenn 52:1-18

Bennett KD (1996) Determination of the number of zones in a biostratigraphical sequence. New Phytol 132:155-170

Berglund BE, Ralska-Jasiewiczowa M (1986) Pollen analysis and pollen diagrams. In: Berglund BE (ed) Handbook of holocene palaeoecology and palaeohydrology. Wiley, Chichester, pp 455-484

Bertolani Marchetti D, Accorsi CA, Arobba D et al (1984) Recherches géobotaniques sur les Monts Madonie (Sicile du Nord). Webbia 38:329-348

Beug H-J (2004) Leitfaden der Pollenbestimmung für Mitteleuropa und angrenzende Gebiete. Pfeil, München

Birks HJB, Gordon AD (1985) Numerical methods in Quaternary pollen analysis. Academic Press, London

Bisculm M, Colombaroli D, Vescovi E et al (2012) Holocene vegetation and fire dynamics in the supra-mediterranean belt of the Nebrodi Mountains (Sicily, Italy). J Quat Sci 27:687-698

Brayshaw DJ, Rambeau CMC, Smith SJ (2011) Changes in Mediterranean climate during the Holocene: insights from global and regional climate modelling. Holocene 21:15-31 
Brullo S, Cormaci A, Giusso del Galdo G, Guarino R, Minissale P, Siracusa G, Spampinato G (2005) A syntaxonomical survey of the Sicilian dwarf shrub vegetation belonging to the class Rumici-Astragaletea siculi. Annali di Botanica 5:57-104

Brullo C, Brullo S, Giusso del Galdo G, Guarino R, Siracusa G, Sciandrello S (2012) The class Querco-Fagetea sylvaticae in Sicily: an example of boreo-temperate vegetation in the central Mediterranean region. Annali di Botanica 2:19-38

Brullo C, Brullo S, Downie SR, Danderson CA, Giusso del Galdo G (2013a) Siculosciadium, a new monotypic genus of Apiaceae from Sicily. Ann Mo Bot Gard 99:1-18

Brullo C, Brullo S, Giusso del Galdo G (2013b) Considerations on the endemic flora of Sicily. In: Cardona Pons E, Estaún Clarisó I, Comas Casademon M, Fraga i Arguimbau P (eds) Islands and plants: preservation and understanding of flora on Mediterranean Islands. Maó, Institut Menorquí d'Estudis, Consell Insular de Menorca, Es Mercadal, pp 177-1999

Büntgen U, Tegel W, Nicolussi K et al (2011) 2500 Years of european climate variability and human susceptibility. Science 331:578-582

Cacho I, Grimalt JO, Canals M, Sbaffi L, Shackleton NJ, Schonfeld J, Zahn R (2001) Variability of the western Mediterranean Sea surface temperature during the last 25,000 years and its connection with the Northern Hemisphere climatic changes. Paleoceanography 16:40-52

Calò C, Henne PD, Curry B et al (2012) Spatio-temporal patterns of Holocene environmental change in southern Sicily. Paleogeogr Paleoclimatol Paleoecol 323:110-122

Calò C, Henne PD, Eugster P et al (2013) 1200 years of decadal-scale variability of Mediterranean vegetation and climate at Pantelleria Island, Italy. Holocene 23:1,477-1,486

Carrión JS (2002) Patterns and processes of Late Quaternary environmental change in a montane region of southwestern Europe. Quat Sci Rev 21:2,047-2,066

Carrión JS, Fernández S, Jiménez-Moreno G et al (2010) The historical origins of aridity and vegetation degradation in southeastern Spain. J Arid Environ 74:731-736

Colombaroli D, Tinner W (2013) Determining the long-term changes in biodiversity and provisioning services along a transect from Central Europe to the Mediterranean. Holocene 23:1,477-1,486

Colombaroli D, Marchetto A, Tinner W (2007) Long-term interactions between Mediterranean climate, vegetation and fire regime at Lago di Massaciuccoli (Tuscany, Italy). J Ecol 95:755-770

Conedera M, Tinner W, Neff C, Meurer M, Dickens AF, Krebs P (2009) Reconstructing past fire regimes: methods, applications, and relevance to fire management and conservation. Quat Sci Rev 28:555-576

Cullotta S, Pasta S (2004) Vegetazione mediterranea: Sicilia, Sardegna, Calabria. In: Blasi C et al (eds) Incendi e complessità ecosistemica. Dalla pianificazione forestale al recupero ambientale. Ministero dell'Ambiente e della Tutela del Territorio \& Società Botanica Italiana, Palombi \& Partner, Rome, pp 291-307

Czucz B, Galhidy L, Matyas C (2011) Present and forecasted xeric climatic limits of beech and sessile oak distribution at low altitudes in Central Europe. Ann For Sci 68:99-108

Davis BAS, Collins PM, Kaplan JO (2015) The age and post-glacial development of the modern European vegetation: a plant functional approach based on pollen data. Veget Hist Archaeobot 24:303-317

Demesure B, Comps B, Petit RJ (1996) Chloroplast DNA phylogeography of the common beech (Fagus sylvatica L) in Europe. Evolution 50:2,515-2,520

Di Benedetto L, Maugeri G, Poli Marchese E (1984) Principali tappe del dinamismo della vegetazione nelle Sugherete della Sicilia sud-orientale. Notiziario Fitosociologico 19:5-12
Ellenberg H (2009) Vegetation ecology of Central Europe. Cambridge University Press, Cambridge

Federici MF, Mangialardi C (1995) Prospetto delle associazioni vegetali riferibili alla classe Quercetea ilicis in Italia. Atti dei Convegni dei Lincei 115:391-404

Finsinger W, Tinner W (2005) Minimum count sums for charcoalconcentration estimates in pollen slides: accuracy and potential errors. Holocene 15:293-297

Finsinger W, Colombaroli D, De Beaulieu J-L et al (2010) Early to mid-Holocene climate change at Lago dell'Accesa (central Italy): climate signal or anthropogenic bias? J Quat Sci $25: 1,239-1,247$

Frei M (1940) Die Pflanzen-Assoziationen der alpinen Stufe des Ätna. Berichte des Geobotanischen Forschunginstituts Rübel-Zürich 1939:86-92

Frisia S, Borsato A, Mangini A, Spötl C, Madonia G, Sauro U (2006) Holocene climate variability in Sicily from a discontinuous stalagmite record and the Mesolithic to Neolithic transition. Quat Res 66:388-400

Guarino R, Giusso Del Galdo G, Pignatti S (2006) The Mediterranean dwarf shrubs: origin and adaptive radiation. Annali di Botanica 5:93-101

Heegaard E, Birks HJB, Telford RJ (2005) Relationships between calibrated ages and depth in stratigraphical sequences: an estimation procedure by mixed-effect regression. Holocene 15:612-618

Henne PD, Elkin C, Franke J et al (2015) Reviving extinct Mediterranean forests increases ecosystem potential in a warmer future. Front Ecol Environ 13:356-362

Hewitt GM (1999) Post-glacial re-colonization of European biota. Biol J Linn Soc 68:87-112

Howe S, Webb T III (1983) Calibrating pollen data in climatic terms: improving the methods. Quaty Sci Rev 2:17-51

Juggins S (1991) ZONE Software. University of Newcastle upon Tyne, Tyne and Wear

Lang G (1994) Quartäre Vegetationsgeschichte Europas: Methoden und Ergebnisse. Fischer, Jena

Leighton R (1999) Sicily before history: an archaeological survey from the Palaeolithic to the Iron Age. Cornell University Press, New York

Lentini F, Carbone S (2014) Geologia della Sicilia - Geology of Sicily. Memorie Descr. Carta Geologica d'Italia 95:7-414

Luterbacher J, García-Herrera R, Akcer-On S et al (2012) A review of 2000 years of Paleoclimatic evidence in the Mediterranean. In: Lionello P (ed) The climate of the Mediterranean region-from the past to the future. Elsevier, Amsterdam, pp 87-185

Magny M, Vannière B, Calò C et al (2011) Holocene hydrological changes in south-western Mediterranean as recorded by lakelevel fluctuations at Lago Preola, a coastal lake in southern Sicily, Italy. Quat Sci Rev 30:2,459-2,475

Magny M, Peyron O, Sadori L, Ortu E, Zanchetta G, Vannière B, Tinner W (2012) Contrasting patterns of precipitation seasonality during the Holocene in the south- and north-central Mediterranean. J Quat Sci 27:290-296

Maise C (1998) Archäoklimatologie - Vom Einfluss nacheiszeitlicher Klimavariabilität in der Ur- und Frühgeschichte. Jahrb Schweiz Ges Ur- und Frühgesch 81:197-235

Marchal O, Cacho I, Stocker TF et al (2002) Apparent long-term cooling of the sea surface in the northeast Atlantic and Mediterranean during the Holocene. Quat Sci Rev 21:455-483

Maugeri G, Leonardi S (1974) Esempio di macchia a Ginepro e Lentisco nella Sicilia meridionale. Archivio Botanico e Biogeografico Italiano 50:51-60

Médail F, Diadema K (2009) Glacial refugia influence plant diversity patterns in the Mediterranean Basin. J Biogeogr 36:1,333-1,345 
Mercuri AM, Mazzanti MB, Torri P et al (2012) A marine/terrestrial integration for mid-late Holocene vegetation history and the development of the cultural landscape in the Po valley as a result of human impact and climate change. Veget Hist Archaeobot $21: 353-372$

Moore PD, Webb JA, Collinson ME (1991) Pollen analysis, 2nd edn. Blackwell Scientific Publications, London

Morales-Molino C, García-Antón M (2014) Vegetation and fire history since the last glacial maximum in an inland area of the western Mediterranean Basin (Northern Iberian Plateau, NW Spain). Quat Res 81:63-77

Muller SD, Rhazi L, Andrieux B et al (2015) Vegetation history of the western Rif mountains (NW Morocco): origin, late-Holocene dynamics and human impact. Veget Hist Archaeobot 24:487501

Noti R, van Leeuwen JFN, Colombaroli D et al (2009) Mid- and lateHolocene vegetation and fire history at Biviere di Gela, a coastal lake in southern Sicily, Italy. Veget Hist Archaeobot 18:371-387

ODA (2015) Osservatorio della Acque. Annali, termometria e pluviometria. Regione Siciliana. http://www.osservatorioacque. it/

Pérez-Sanz A, González-Sampériz P, Moreno A et al (2013) Holocene climate variability, vegetation dynamics and fire regime in the central Pyrenees: the Basa de la Mora sequence (NE Spain). Quat Sci Rev 73:149-169

Pignatti S (1997) Ecologia del paesaggio. Unione TipograficoEditrice Torinese (UTET), Torino

Punt W et al. (1976-1996) The Northwest European Pollen Flora (NEPF) vol 1 (1976), vol 2 (1980), vol 3 (1981), vol 4 (1984) vol 5 (1988), vol 6 (1991), vol 7 (1996). Elsevier, Amsterdam

Punt W, Blackmore S, Nilsson S, Le Thomas A (1994) Glossary of pollen and spore terminology. LPP Contrib Ser 1:1-71

Reed JM, Stevenson AC, Juggins S (2001) A multi-proxy record of Holocene climatic change in southwestern Spain: the Laguna de Medina, Cadiz. Holocene 11:707-719

Reille M (1992) Pollen et spores d'Europe et d'Afrique du nord. Laboratoire de Botanique hostorique et Palynologie, Marseille

Reimer PJ, Bard E, Bayliss A, Beck JW, Blackwell PG, Ramsey CB, Buck CE, Cheng H, Edwards RL, Friedrich M, Grootes PM, Guilderson TP, Haflidason H, Hajdas I, Hatte C, Heaton TJ, Hoffmann DL, Hogg AG, Hughen KA, Kaiser KF, Kromer B, Manning SW, Niu M, Reimer RW, Richards DA, Scott EM, Southon JR, Staff RA, Turney CSM, van der Plicht J (2013) Intcal13 and Marine13 radiocarbon age calibration curves 0-50,000 years cal BP. Radiocarbon 55:1,869-1,887

Reisigl H, Danesch E, Danesch O (1992) Mittelmeerflora. Parkland, Stuttgart

Sadori L, Narcisi B (2001) The Postglacial record of environmental history from Lago di Pergusa, Sicily. Holocene 11:655-671

Sadori L, Jahns S, Peyron O (2011) Mid-Holocene vegetation history of the central Mediterranean. Holocene 21:117-129
Sadori L, Masi A, Ricotta C (2015) Climate-driven past fires in central Sicily. Plant Biosyst 149:166-173

Schwörer C, Henne PD, Tinner W (2014) A model-data comparison of Holocene timberline changes in the Swiss Alps reveals past and future drivers of mountain forest dynamics. Glob Chang Biol $20: 1,512-1,526$

Seppä H, Birks HJB, Odland A, Poska A, Veski S (2004) A modern pollen-climate calibration set from northern Europe: developing and testing a tool for palaeoclimatological reconstructions. J Biogeogr 31:251-267

Stockmarr J (1971) Tablets with spores used in absolute pollen analysis. Pollen Spores 13:615-621

Tinner W, Ammann B (2005) Long-term responses of mountain ecosystems to environmental changes: Resilience, adjustment, and vulnerability. In: Huber UM, Bugmann H, Reasoner M (eds) Global change and mountain research-state of knowledge overview. Springer, Dordrecht, pp 133-144

Tinner W, Hu FS (2003) Size parameters, size-class distribution and area-number relationship of microscopic charcoal: relevance for fire reconstruction. Holocene 13:499-505

Tinner W, Conedera M, Ammann B, Gäggeler HW, Gedye S, Jones R, Sägesser B (1998) Pollen and charcoal in lake sediments compared with historically documented forest fires in southern Switzerland since AD 1920. Holocene 8:31-42

Tinner W, Lotter AF, Ammann B, Conedera M, Hubschmid P, van Leeuwen JFN, Wehrli M (2003) Climatic change and contemporaneous land-use phases north and south of the Alps $2300 \mathrm{BC}$ to 800 AD. Quat Sci Rev 22:1,447-1,460

Tinner W, Van Leeuwen JFN, Colombaroli D, Vescovi E, van der Knaap WO, Henne PD, Pasta S, D'Angelo S, La Mantia T (2009) Holocene environmental and climatic changes at Gorgo Basso, a coastal lake in southern Sicily, Italy. Quat Sci Rev 28:1,498-1,510

Tinner W, Colombaroli D, Heiri O, Henne PD, Steinacher M, Untenecker J, Vescovi E, Allen JRM, Carraro G, Conedera M, Joos F, Lotter AF, Luterbacher J, Samartin S, Valsecchi V (2013) The past ecology of Abies alba provides new perspectives on future responses of silver fir forests to global warming. Ecol Monogr 83:419-439

Tinner W, Beer R, Bigler C, Clegg BF, Jones RT, Kaltenrieder P, van Raden UJ, Gilli A, Hu FS (2015) Late-Holocene climate variability and ecosystem responses in Alaska inferred from high-resolution multiproxy sediment analyses at Grizzly Lake. Quat Sci Rev 126:41-56

Viola F, Liuzzo L, Noto LV, Lo Conti F, La Loggia G (2014) Spatial distribution of temperature trends in Sicily. Int $\mathrm{J}$ Climatol 34:1-17

Wirtz KW, Lemmen C (2003) A global dynamic model for the neolithic transition. Clim Change 59:333-367 